\title{
A New Era in Fintech Payment Innovations? A Perspective from the Institutions and Regulation of Payment Systems
}

\section{Iris H-Y Chiu*}

\section{Abstract and Introduction}

The growth of financial technology is a marked trend as Price Waterhouse Coopers observes fintech as 'a dynamic segment at the intersection of the financial services and technology sectors where technology-focused start-ups and new market entrants innovate the products and services currently provided by the traditional financial services industry'. ${ }^{1}$ Fintech reaches into many areas of financial services, from products to services and markets, ${ }^{2}$ and many aspects could be poised to be 'disruptive innovations', which, in Bower and Christensen's framework, ${ }^{3}$ refer to the creation of new markets and value networks that eventually disrupt existing markets and value networks, displacing established market leaders and alliances. Fintech in payment innovations seems promising in revolutionising the way we pay and how money is transferred.

The advancement of technological possibilities alone is usually not a sufficient predictor of their disruptive potential. ${ }^{4}$ This paper places payment innovations within a payment system. The payment system comprises of initiation of payment, transfer as well as clearing and settlement. We argue that existing payment systems are defined by certain institutional tenets that serve commercial objectives but more importantly, deliver public goods and public interest objectives for users and policy-makers. This perspective sets the context for discussing the prospects of competition, and shows that the disruptive potential of modern competitors in payment services may be more nuanced than hyped. In other words, pro-competition in regulatory policy should not be regarded as an unequivocal good.

Three types of payment innovations have been hailed to have disruptive potential in recent developments. First, innovations in retail payment interfaces or options at point of sale, such as mobile or app payments, that may displace the use of cash and cards. Second, virtual currencies such as Bitcoin may come to be accepted as legitimate forms of payment by merchants and businesses. Third, new technologies such as the distributed ledger or autonomous organisation technologies may replace existing infrastructure in payment clearing and settlement systems.

Section A discusses the institutionalisation of certain tenets in existing payment systems. We discuss large value transfer systems and retail payment systems separately as these have evolved in different ways. It may be questioned if new technology has the potential to break down these

\footnotetext{
*Professor of Corporate Law and Financial Regulation, University College London. This paper is commissioned by the Centre for Law, Economy and Society and the author thanks loannis Lianos for earlier discussions on this topic, and Roger Brownsword for very helpful comments on an earlier draft. All errors are mine.

${ }^{1}$ Price Waterhouse Coopers, Blurred Lines: How Fintech is Shaping the Financial Services Industry (March 2016).

${ }^{2}$ An overview of which is provided in Iris $\mathrm{H}-\mathrm{Y}$ Chiu, 'Fintech and Disruptive Business Models in Financial Products, Intermediation and Markets - Policy Implications for Financial Regulators (2016) 21 Journal of Technology Law and Policy 168.

${ }^{3}$ Joseph Bower and Clayton Christensen, 'Disruptive Technologies: Catching the Wave' (1995) Harvard Business Review 43-53; Clayton Christensen and M Raynor, The Innovator's Solution (Harvard Business School Press, 2003).

${ }^{4}$ Stefan W. Schmitz, 'The Political Economy of Institutional Change in the Payment System and Monetary Policy' (2006) at http://ssrn.com/abstract=944404.
} 
established 'categories' of payment development, but we show that the separate developments are also in large part due to public policy objectives. We establish the key institutional tenets of payment systems in both large value and retail payment architecture and show that they have evolved to secure efficiency for users in the discharge of payments, but also public policy objectives in safety, confidence and consumer protection in the commercial conduct of payment. This discussion is based chiefly on developments in the UK, EU and US where institutional maturity has been achieved. Arguably the same commercial objectives and public policy needs subsist more widely, and large value transfer systems are very similar worldwide. Even in retail payment systems where certain institutional tenets are not highly developed in some jurisdictions, our discussion relates to issues of common interest.

Section B then discusses each of the three types of payment innovation identified in this article. We raise key examples observed across a number of different parts of the world, and discuss their compatibility or 'substitutive potential' ${ }^{5}$ with the institutions of payment systems discussed earlier. This Section critically discusses if each type of payment innovation has the potential to bring about institutional change. Section $\mathrm{C}$ concludes.

\section{A. The Institutionalisation of Fundamental Tenets in Payment Systems}

Payment, an act involving the giving and receipt of value, is usually effected in processes involving a number of intermediaries, constituting a payment system. This is because payment is not always made via the physical tender of cash between bilateral parties at the same location, which achieves the completion and finality of payment. Where parties are not at the same physical location, and physical cash is not used, the transfer of value to achieve payment involves processes where intermediaries perform the functions of verifying identities, payment instructions, source of funds, location of receipt, execution of payment, and ledger adjustments on the part of the entities serving the giver and receiver, so as to achieve final settlement where all risks in the payment processes are discharged. In the words of a couple of commentators, payment involves 'custodians, cash correspondents, clearing members, ..., settlement agents...' constituting a payment system. ${ }^{6}$

The payment system is a system of coordinating intermediaries for the payor and payee. In such a coordinating paradigm, the payor runs the risk of agency costs in terms of the efficiency and cost at which the payment is effected; the risk of default costs in terms of the solvency of the intermediaries effecting the payment; and the risk of legal costs if the payment is defectively effected or not at all, resulting in legal risk of public or private law enforcement against the payor. The payee runs the risk of the same agency costs, the risk of default costs in terms of the solvency of the intermediaries or the payor, and the same risk of legal costs. Intermediaries also incur risks, as their desire to lower agency cost may result in their advancing of liquidity between payor and payee before settlement is achieved, and thus incur the risk of default costs if the payor should become insolvent. ${ }^{7}$ Further,

\footnotetext{
${ }^{5}$ This is discussed in Iris $\mathrm{H}-\mathrm{Y}$ Chiu, 'Fintech and Disruptive Business Models in Financial Products, Intermediation and Markets - Policy Implications for Financial Regulators (2016) 21 Journal of Technology Law and Policy 168 as part of a three-pronged theoretical framework for analysing the disruptive potential in a number of areas in fintech, and the implications for regulatory policy.

${ }^{6}$ Andre Pinna and Wieber Ruttenberg, 'Distributed Ledger Technologies In Securities Post-Trading' (ECB Occasional Paper 2016).

${ }^{7}$ Risks in payment systems see Jean-Charles Rochet and Jean Tirole, 'Controlling Risk in Payment Systems' (1996) 28 Journal of Money, Credit and Banking 832.
} 
intermediaries may incur the risk of legal costs in disputed payments on the basis of fraud, mistake or legal non-compliance. The need to minimise transaction costs is a key driver for certain coordination mechanisms to have arisen in payment systems. This is one driver for the institutionalisation of certain fundamental tenets in payment systems, in particular the tenets relating to efficiency and risk mitigation.

The theoretical lens of economic institutionalisation sheds some light on how institutions of payment systems arose. Coase ${ }^{8}$ and North developed the perspectives that economic organisation is driven by the need to minimise transaction costs, and that 'institutions', which are defined as 'humanly devised constraints that structure political, economic and social interaction' ${ }^{9}$ are sets of informal or formal rules that arise out of the need to minimise the cost of uncertainties in exchange. In a paradigm of necessary coordination amongst many intermediaries effecting a payment transaction between payor and payee, efficiency-based drivers have been important to cementing a set of institutions that mitigate the risks on all sides discussed above.

Further, as payment systems enjoy network effects, ${ }^{10}$ becoming spheres of highly coordinated connectivity of socio-economic relations, the economy and society perspective ${ }^{11}$ provides further support for understanding how certain fundamental tenets in payment systems become institutions of social confidence and trust. We see the network effects of payment systems as a sociological phenomenon reflecting private sector cooperation as well as private and public sector coordination, ${ }^{12}$ beyond what is merely efficient, in order to maintain what has become a 'public infrastructure ${ }^{13}$ or collective good.

The establishment of certain institutions in payment systems, including by regulation, induces social confidence and trust, sustaining the public infrastructure or collective good. Social trust has been characterised as the necessary 'bridge' between transaction (contract) and execution (which is payment and settlement). ${ }^{14}$ Two dimensions of social trust conceptualised by Preda ${ }^{15}$ can be observed: one is that the network effects of payment systems engender and reinforce social

\footnotetext{
${ }^{8}$ Ronald C Coase, 'The Nature of the Firm' (1937) 4 Economica 386.

${ }^{9}$ Douglass C North, 'Institutions' (1991) 5 Journal of Economic Perspectives 97.

${ }^{10}$ For eg see Wilko Bolt, 'Retail Payment Systems: Competition, Innovation and Implications' (2012) at http://ssrn.com/abstract=2192046; Jane Kaufman Winn, 'Clash of the Titans: Regulating the Competition between Established and Emerging Electronic Payment Systems' (1999)14 Berkeley Tech. L.J. 675; Stefan W. Schmitz, 'The Political Economy of Institutional Change in the Payment System and Monetary Policy' (2006) at http://ssrn.com/abstract=944404.

${ }^{11}$ Bruce G Carruthers and Sarah L Babb, Economy \& Society (2nd ed, Boston: Sage 2013) at chapter 4.

${ }^{12} \mathrm{~A}$ co-regulatory relationship as discussed in Jane K. Winn, 'Governance of Global Mobile Money Networks: The Role of Technical Standards' (2013) 8 Wash. J.L. Tech. \& Arts 197-244; Mark Edwin Burge, 'Apple Pay, Bitcoin, and Consumers: The ABCs of Future Public Payments Law' (2016) 67 Hastings Law Journal 1493; Agnieszka Janczuk-Gorywoda, 'Evolution of EU Retail Payments Law' (2015) at http://ssrn.com/abstract=2694426 and will be elaborated on further.

${ }^{13}$ Andrew G Haldane and Edwin Latter, 'The Role of Central Banks in Payment Systems Oversight' (2005) at http://papers.ssrn.com/sol3/papers.cfm?abstract id=698802; Henri Pagés and David Humphrey, 'Settlement Finality as a Public Good in Large Value Transfer Systems' (2005) at http://papers.ssrn.com/sol3/papers.cfm?abstract id=750786, and Agnieszka Janczuk-Gorywoda, 'Evolution of EU Retail Payments Law' (2015) at http://ssrn.com/abstract=2694426.

${ }^{14}$ Catherine Martin Christopher, 'The Bridging Model: Exploring the Roles of Trust and Enforcement in Banking, Bitcoin and Blockchain' (2017) 17 Nevada Law Journal 1.

${ }^{15}$ Alex Preda, Information, Knowledge and Economic Life (Oxford: OUP 2009) at chapters 1 and 2.
} 
confidence and trust in the norms and expected behaviour within the community; the second is that such norms and expected behaviour are supported by law and regulation which achieve commercial objectives of efficiency and public interest objectives in safety, therefore strengthening the network effects of payment systems.

We also think that there may be a case for considering whether the sociological phenomenon of trust in professionalised or expert systems is important to sustaining social confidence and trust in existing payment systems. ${ }^{16}$ The 'professionalised' or 'expert' quality in existing payment systems is very much bound up in the established nature of certain payment intermediary businesses, chiefly banks, ${ }^{17}$ that have enjoyed a high level of public trust, which although damaged after the global financial crisis $2007-9,{ }^{18}$ is to a large extent being repaired by a greatly enhanced level of regulatory control. ${ }^{19}$ Further, social confidence or trust may be reposed in the key institution of central bank support in payment systems, a fundamental tenet that we will discuss in greater detail. The central bank, seen in many jurisdictions as the keeper of economic health, and usually independent of governments, is still trusted as a technocracy that can deliver public interest in overall economic welfare..$^{20}$ This central institution of many payment systems in no small part underpins social confidence and trust in existing payment systems.

The institutional perspective of payment systems is an important one. This is because institutions, embodied in norms of formal and informal types that relate to standards, procedures and outcomes, are a culmination of shared expectations and objectives, and provide an enduring system of meeting them. The enduring quality of such a system is not necessarily a stagnation and ossification, but can be seen as serving fundamental premises and needs. At a higher level, this argument is advanced by Acemoglu and Robinson ${ }^{21}$ to explain why certain nations hold on to the outcomes of stability and prosperity while others fail. They are of the view that the institutional choices made by countries play a key part in determining the ultimate outcomes, a key institution being that of democracy. ${ }^{22}$ In

\footnotetext{
${ }^{16}$ Above at chapter 3 .

17 The domination of banks will be discussed shortly.

${ }^{18}$ For eg Luiz Carlos Bresser-Pereira, 'The Global Financial Crisis and a new Capitalism' (May 2010, Levy Economics Institute); Richard D Wolff, Capitalism's Crisis Deepens: Essays on the Global Economic Meltdown (Haymarket Books 2016).

${ }^{19}$ This is an international development led by the Basel III Capital Accord, see Basel Committee on Banking Supervision, Basel III: A Global Regulatory Framework for More Resilient Banks and Banking Systems (rev June 2011, Basel: BIS 2010) <http://www.bis.org/publ/bcbs189.pdf, and other reforms such as crisis management and bank structure, adopted to different extents in the US, the EU and UK, see for example the EU Bank Recovery and Resolution Directive 2014, discussed in Michael Schillig, Resolution and Insolvency of Banks and Financial Institutions (Oxford: OUP 2016); and the UK's ring-fencing reforms designed to promote trust and confidence in retail banks, see Independent Commission on Baking, Final Report: Recommendations (Sep 2011) at http://webarchive.nationalarchives.gov.uk/20131003105424/https:/hmtsanctions.s3.amazonaws.com/ICB\%20final\%20report/ICB\%2520Final\%2520Report\%5B1\%5D.pdf; HM Treasury and Department of Business, Skills and Innovation, Banking Reform: Delivering Stability and Supporting a Sustainable Economy (June 2012) at https://www.gov.uk/government/uploads/system/uploads/attachment data/file/32556/whitepaper banking reform 140512.pdf.

${ }^{20}$ For eg Mohamed El Erian, The Only Game in Town: Central Banks, Instability, and Avoiding the Next Collapse (NY: Random House 2016).

${ }^{21}$ Daron Acemoglu and James A Robinson, Why Nations Fail: The Origins of Power, Prosperity, and Poverty (NY: Crown Business, 2012)

22 That inclusive institutions where people play a larger part in shaping political and governance decisions fared better than extractive institutions which supported the distribution of power to the elite few.
} 
the much narrower application to this article, institutions are arguably key to the outcomes of reliability and safety in payment systems, both desired from the points of view of economic efficiency as well as public good. Taking such an institutional view of the payment system sets the context for analysing the place for commercially-driven competition and the potential achievements of disruptive payment innovations. ${ }^{23}$

At this juncture it may be argued that the institutions of payment systems, driven by efficiency factors and public policy have merely established a highly entrenched structure that is susceptible to uncompetitive practices, such as high cost, poor service standards and unresponsiveness to user needs. An institutional perspective of the payment system must not merely reinforce the incumbents' stranglehold upon the payment system. We acknowledge that these are valid concerns, but the network effects of existing payment systems are not merely a commercial phenomenon. They reflect public policy interests and objectives, and the socio-economic behaviour of users and intermediaries. ${ }^{24}$ Hence a balanced perspective should be taken- arguably that market competition and commercial innovations should be fostered where those are superior in delivering social benefits but in a manner that does not compromise the protection of public goods.

We devote some space to examining the key institutions in large value and retail payment systems respectively. In large value payment systems we see how meeting commercial outcomes and public good have converged into key institutions for payment dominated by banks as actors in the payment system. In retail payment systems, bank domination has however produced market failures that are now addressed by consumer protection regulation. The implications of consumer protection are key in defining the institutions that need to be maintained in retail payment systems.

\section{The Institutions of Large Value Payment Systems}

The commercial needs of business transactions demand payment processes that can achieve large value transfers ${ }^{25}$ within as short as possible a timeframe. Risk mitigation is improved with the shorter time period taken for large payments to be processed and settled, as agency, default and legal risks on all sides are minimised. ${ }^{26}$ Large value transfers are also a significant generator of revenue for all payment intermediaries. ${ }^{27}$ The commercial incentives in processing large value payments have culminated in coordination mechanisms domestically and internationally. A key

\footnotetext{
${ }^{23}$ Stefan W. Schmitz, 'The Political Economy of Institutional Change in the Payment System and Monetary Policy' (2006) at http://ssrn.com/abstract=944404.

${ }^{24}$ Reflecting the Polanyi perspective of the social embeddedness of markets, see Carlo Trigilia, Economic Sociology (Oxford: Blackwell 2002) at chapter 1.

25 'Large value' is not a sharply defined minimum, for example the US FEDWIRE reports a median value of USD\$35,000 in 2008, see p70, Morten L. Bech, Christine Preisig, and Kimmo Soramäki, 'Global Trends in Large Value Payments' (2008) Federal Reserve Bank of New York Economic Policy Review 59 at https://www.newyorkfed.org/medialibrary/media/research/epr/08v14n2/0809prei.pdf.

${ }^{26}$ Jean-Charles Rochet and Jean Tirole, 'Controlling Risk in Payment Systems' (1996) 28 Journal of Money, Credit and Banking 832; Henri Pagés and David Humphrey, 'Settlement Finality as a Public Good in Large Value Transfer Systems' (2005) at http://papers.ssrn.com/sol3/papers.cfm?abstract id=750786 but see Peter Galos and Kimmi Soramãki, 'Systemic Risk in Alternative Payment System Designs' (2005) at http://papers.ssrn.com/sol3/papers.cfm?abstract id $=750788$ where it is argued that the systemic risk implications of one insolvent bank is likely to be insignificant.

${ }^{27}$ Eg the figures surveyed in Morten L. Bech, Christine Preisig, and Kimmo Soramäki, 'Global Trends in Large Value Payments' (2008) Federal Reserve Bank of New York Economic Policy Review 59 at https://www.newyorkfed.org/medialibrary/media/research/epr/08v14n2/0809prei.pdf.
} 
institution that underpins the domestic large value transfer systems like CHAPS in the UK, ${ }^{28}$ TARGET2 in the $\mathrm{EU}^{29}$ and Fedwire in the $\mathrm{US}^{30}$ is a coordinated network of entities carrying out payment clearing and settlement. The network is however bank-dominated, as mutual trust persists among peer clearing entities. The existence of mutual trust is in no small part due to central bank support, which we discuss shortly, as being key to giving clearing entities their peer regard inter se. Central bank support exists pursuant to the public interest objectives underlying the maintenance of stable, reliable and risk-managed large value transfer systems, firmly establishing the public good nature of payment infrastructure as critical infrastructure. In sum, the key institutions of large value payment systems, whether national or international, feature these three key institutional tenets of a network of peer clearing entities enjoying central bank support which underlie the achievement of both commercial objectives and public good.

In the UK, the national large value payment system is the Clearing House Automated Payment System (CHAPS). CHAPS was formed in 1984 to offer a same-day clearing and settlement service for large value transfers. CHAPS was formed as a company by banks that were members of the Association of Payments and Clearing Services (APACS), now a not-for-profit organisation known as UK Payments Administration. ${ }^{31}$ The Bank of England was admitted as an inaugural member but also a member as of right. ${ }^{32}$ The set-up of CHAPS reflected the ethos of a network of private sector banks which regarded each other as peers in order to carry out the multilateral coordination needed for clearing and settlement, tasks that needed to be strongly anchored in trust. ${ }^{33}$ These peer clearing banks all maintain clearing accounts at the Bank of England. These mutually trusting relationships underpinned the largely self-regulating nature of the large value transfer system for a long time ${ }^{34}$ in delivering commercial needs for the purposes of overall social good and utility. CHAPS remains a membership-based organisation with 20 banks in its membership that have the common stake of being a 'shareholder' in the corporate structure of CHAPS. Its membership list now includes several large foreign banks and not just UK-domiciled banks.

CHAPS, as a membership-based organisation, is a reflection of the Coasean theory of internalisation of transaction costs. As peer members in a common organisation, CHAPS participants trust each other to clear payment mandates (ie to verify senders' identities, instructions etc) and process payment instructions in order to credit the designated payees. This is far more efficient than a bilateral correspondent banking system, where banks would have to maintain accounts with each other. Settlement would have to take place at the level of peer accounts maintained with a common entity as only the adjustment of account balances maintained at a common independent entity

\footnotetext{
${ }^{28}$ http://www.chapsco.co.uk/.

${ }^{29}$ https://www.ecb.europa.eu/paym/t2/html/index.en.html.

${ }^{30}$ https://frbservices.org/fedwire/index.html.

${ }^{31}$ https://www.ukpayments.org.uk/our-story/.

32 See section 6, CHAPS' Memorandum of Association available at the Companies House website.

${ }^{33}$ Described by Carlo Edoardo Altamura, European Banks and the Rise of International Finance: The postBretton Woods Era ( Oxford: Routledge 2016) as a culture of 'co-operative banking' where banks performing similar services and functions treat each other as peers and such multilateral relationships coalesce into trade associations.

${ }^{34}$ As seen in the approach taken in the case of United Dominions Trust Ltd v Kirkwood [1966] 2 QB 431, and the reticent approach taken to banking regulation in the first Banking Act 1979. The Bank of England's peer treatment of the 'City of London' banks is extensively discussed in Richard Fry, Banker's World: The Revival of the City 1957-1970 (Oxford: Routledge 2013).
} 
achieves objective and final settlement. This would occur at the central bank. Therefore the need to achieve settlement finality based on central bank accounts becomes undoubtedly a condition that delimits the boundaries of membership in CHAPS, as only banking institutions meeting a reserve requirement would be eligible for accounts at the central bank. ${ }^{35}$ Although subsequent legislation in The Financial Markets and Insolvency (Settlement Finality) Regulations 1999 has not limited participation in CHAPS to only banks, the conditions of participation could be regarded as skewed towards banks in terms of the regulatory thresholds and compliance that need to be met.

Central bank support is an institution of efficiency, providing the 'ultimate settlement asset' for all participants. ${ }^{36}$ However, it is also increasingly a means of channelling public policy influence into shaping and maintaining the large value payment system. This is because despite the essentially private nature of the payment system, the large value payment system is regarded as public infrastructure ${ }^{37}$ which causes systemic implications if problems occur. If the insolvency of one bank or two in the system causes a knock-on effect upon others, systemic failures and instability can arise. The Bank of England has been reposed with a mandate to maintain financial stability, and therefore engages in policies affecting risk mitigation and overall oversight in the payment system, in order to maintain stature of the payment system as public infrastructure capable of continuity even in stressed times. Hence clearing banks in the UK are imposed with obligations to maintain business continuity if crises occur. They are subject to regulatory oversight in terms of recovery and resolution planning ${ }^{38}$ as well as stress-testing. ${ }^{39}$ Public policy and prudential regulation in the UK support the establishment of key payment institutions in the form of the network or coterie of 'peer' clearing entities supported by central bank support. This is because these institutions are crucial to settlement and finality which ultimately affect the systemic risks of the payment system.

Central banks have also played a significant part in establishing risk mitigation policies in large value transfer systems. The Bank of England encouraged the move by CHAPS to replace a settlement process known as 'Deferred Net Settlement' (DNS) with 'Real-time Gross Settlement' (RTGS) by 1996. The reliability and speed of payment clearing and settlement in large value transfers is not only regarded as a commercial service that private payment services providers would be incentivised to

\footnotetext{
${ }^{35}$ This remains the case today although subsequent legislationThe Financial Markets and Insolvency (Settlement Finality) Regulations 1999 has not limited participation to banks. The conditions of participation would however be skewed towards banks.

${ }^{36}$ Stephen Millard and Victoria Saporta, 'Central Banks and Payment Systems; Past, Present and Future' in Andrew G Haldane, Stephen Millard and Victoria Saporta (eds), The Future of Payment Systems (London: Routledge, 2005) at chapter 1.

${ }^{37}$ Stephen Millard and Victoria Saporta, 'Central Banks and Payment Systems; Past, Present and Future' in Andrew G Haldane, Stephen Millard and Victoria Saporta (eds), The Future of Payment Systems (London: Routledge, 2005) at chapter 1; Andrew G Haldane and Edwin Latter, 'The Role of Central Banks in Payment Systems Oversight' (2005) at http://papers.ssrn.com/sol3/papers.cfm?abstract_id=698802.

38 PRA Rulebook, Recovery Plans, PRA Rulebook, Resolution Pack; Bank Recovery and Resolution Order No. 2 , 2014 at http://www.legislation.gov.uk/uksi/2014/3348/pdfs/uksi_20143348 en.pdf; PRA, Supervisory Statement: Recovery Planning (Jan 2015) at http://www.bankofengland.co.uk/pra/Documents/publications/ss/2015/ss1813update.pdf.

${ }^{39}$ Basel Committee, Principles for Sound Stress Testing Practices and Supervision (May 2009) at http://www.bis.org/publ/bcbs155.pdf; PRA, 'The Bank of England's Approach to Stress Testing the UK Banking System' (Oct 2015) at http://www.bankofengland.co.uk/financialstability/Documents/stresstesting/2015/approach.pdf;PRA Rulebook, Internal Capital Adequacy Assessment: Reverse Stress Testing at http://www.prarulebook.co.uk/rulebook/Content/Chapter/302501/13-05-2016.
} 
offer, due to the demands of their users, but also regarded as a desirable standard in the interests of public policy. Until 1996, CHAPS participants would use a system whereby member banks made final settlement between themselves based on the net of inflows and outflows at the end of the settlement cycle or day. Such final settlement is usually made by participant banks across their accounts held at the central bank. DNS was an efficient form of settlement but participants ran the insolvency risk of a counterparty member occurring within the day before end-of-day settlement. ${ }^{40}$ The policy preference for reducing settlement risk from such insolvency risk drove the adoption of the RTGS by CHAPS in 1996. RTGS would ensure within-the-day real-time settlement of large value transfers, by constant crediting and debiting of banks' accounts at the central bank as payment mandates came in. The RTGS provides security of final settlement for users, therefore assuring public confidence which is key to maintaining financial stability. ${ }^{41}$ The RTGS however requires the peer clearing banks to have sufficient liquidity to facilitate these gross settlements of each payment mandate, which can be more costly for them than if they were allowed to net the inflows and outflows at the end of day. Hence the central bank plays the crucial part of supplying intra-day liquidity at little or no cost to peer clearing entities in the system. ${ }^{42}$ The intraday liquidity provision by the central bank is arguably not different from a public backstop for the large value payment system, reflecting the special status of the network of peer clearing entities entitled to such support and the stature of the payment system as public good or infrastructure. ${ }^{43}$

A not dissimilar development is observed in the European TARGET2 large value payment system, which, at a higher level above any member state, is a consolidated real-time gross settlement payment system operated and overseen by the European Central Bank and its member national central banks, in order to clear and settle large value transfers in euro across the European Union. ${ }^{44}$ TARGET2 offers a single platform for clearing and settlement and a single price structure, after having graduated from TARGET which was a previously decentralised system coordinated by the ECB in relation to the central bank settlement systems maintained by each member state. National

\footnotetext{
${ }^{40}$ Henri Pagés and David Humphrey, 'Settlement Finality as a Public Good in Large Value Transfer Systems' (2005) at http://papers.ssrn.com/sol3/papers.cfm?abstract_id=750786.

${ }^{41}$ Above, Jean-Charles Rochet and Jean Tirole, 'Controlling Risk in Payment Systems' (1996) 28 Journal of Money, Credit and Banking 832.

${ }^{42}$ Harry Leinonen and Kimmo Soramäki, 'Optimizing Liquidity Usage and Settlement Speed in Payment Systems' (Bank of Finland Paper 1999) at http://papers.ssrn.com/sol3/papers.cfm?abstract id=228249; Gara $M$ Afonso and Hyun Song Shin, 'Systemic Risk and Liquidity in Payment Systems' (Federal Reserve Staff Working Reports, 2009) at http://ssrn.com/abstract=1297363; Andrew G Haldane, Stephen Millard and Victoria Saporta (eds), The Future of Payment Systems (London: Routledge, 2005) at chapter 6, and see Matthew Willison, 'Real-Time Gross Settlement and Hybrid Payment Systems: A Comparison' (2004) at http://papers.ssrn.com/sol3/papers.cfm?abstract $\mathrm{id}=724042$ suggesting that if not real-time, regular periods of off-setting within the day are necessary to mitigate insolvency risk of payment intermediaries.

${ }^{43}$ Andrew G Haldane, Stephen Millard and Victoria Saporta (eds), The Future of Payment Systems (London: Routledge, 2005) at chapter 8.

${ }^{44}$ See

https://www.ecb.europa.eu/paym/pdf/consultations/draft regulation ecb $2016 \mathrm{xx}$ amending regulation e u no 7952014 on oversight requirements for systemically important payment systems.pdf?0533d9630f 0eb14d7f9cc4a7bcd416d5; Andrew G Haldane, Stephen Millard and Victoria Saporta (eds), The Future of Payment Systems (London: Routledge, 2005) at chapter 12; Henri Pagés and David Humphrey, 'Settlement Finality as a Public Good in Large Value Transfer Systems' (2005) at http://papers.ssrn.com/sol3/papers.cfm?abstract id=750786.
} 
central banks and the clearing banks in each member state are now direct participants in TARGET2 ${ }^{45}$ and cross-border euro transfers can be easily and efficiently processed in one outfit instead of utilising bilateral arrangements of central bank account balances held by member states in each other's central bank. In the UK and EU, payment systems and their participants are regulated by harmonised legislation in relation to their authorisation and central bank oversight in terms their risk management, governance and crisis management. ${ }^{46}$ In particular, insolvency law is disapplied in order not to disrupt the finality of transfer orders and collateral enforcement, so as to protect confidence and stability in payment systems. The ECB also regards TARGET2 as public infrastructure and subjects the system to adequate governance and risk management, as well as the application of the Settlement Finality Directive. ${ }^{47}$

In the US, Fedwire is the equivalent real-time gross settlement system for large value payments, ${ }^{48}$ again underpinned by central bank support (Fedwire is the coordinated effort of all federal reserve banks in the US), for its members. Fedwire participants include most if not all banking corporations in the US, large investment firms and funds, some public agencies, many foreign national central banks and large foreign banks. ${ }^{49}$ In terms of Fedwire participants, the almost 10,000 participants would dwarf the membership of CHAPS or TARGET2, and this would seem contrary to the article's proposition that a special network or coterie of peer clearing entitiess is an institutional feature of large value payment systems. However, we propose that the nature of Fedwire participants is consistent with those of CHAPS and TARGET2. Fedwire participants are largely regulated banks and financial institutions, and foreign national central banks, a composition not dissimilar in nature to CHAPS and TARGET2. Regulated financial institutions provide a basis for the peer standing needed for mutual trust in coordination to achieve settlement and finality, and being eligible for central bank support.

This policy preference ${ }^{50}$ for risk mitigation in the system has reinforced the institutions in large value payment systems as being: the network or coterie of peer clearing entities which are regarded to be delivering commercial objectives and public good through central bank support.

Next, the stability and confidence in payment systems is also anchored in their being free from abuse, such as money laundering of proceeds of crime. Although anti-money laundering regulation cuts across to retail payment too and extends to all institutions that may come into possible contact

\footnotetext{
${ }^{45}$ https://www.ecb.europa.eu/paym/t2/shared/pdf/professionals/participation/List_of_Participants_October_ 2015.pdf.

${ }^{46}$ The Financial Markets and Insolvency (Settlement Finality) Regulations 1999 (and amended) based on the EU Settlement Finality Directive 1998 and consolidated after the 2009 amendments.

${ }^{47}$ See ECB, Draft Regulation amending Regulation (EU) No 795/2014 on oversight requirements for systemically important payment systems (Feb 2017) at https://www.ecb.europa.eu/paym/pdf/consultations/draft_regulation_ecb_2016_xx_amending_regulation_e u_no_795_2014_on_oversight_requirements_for_systemically_important_payment_systems.pdf?0533d9630f 0eb14d7f9cc4a7bcd416d5.

48 Jean-Charles Rochet and Jean Tirole, 'Controlling Risk in Payment Systems' (1996) 28 Journal of Money, Credit and Banking 832.

${ }^{49}$ https://www.frbservices.org/EPaymentsDirectory/fpddir.txt.

${ }^{50}$ Peter Galos and Kimmi Soramãki, 'Systemic Risk in Alternative Payment System Designs' (2005) at http://papers.ssrn.com/sol3/papers.cfm?abstract $\mathrm{id}=750788$ argue that DNS systems are more cost-effective and can be made to work using sufficient collateral posting or multilateral loss mutualisation arrangements. Also see Marco Galbiati and Kimmo Soramäki, 'An Agent-Based Model of Payment Systems' (Bank of England Working Paper 2008) at http://ssrn.com/abstract=1280904.
} 
with proceeds of crime such as casinos, real estate agents etc, ${ }^{51}$ financial institutions are especially susceptible to providing the conduits for money laundering and are hence under the regulatory spotlight. There is now extensive regulation of banks and financial institutions in terms of customer due diligence, ${ }^{52}$ internal control and anti-money laundering procedures and alerting systems, ${ }^{53}$ as well as suspicious reporting to the authorities..$^{54}$ Anti-money laundering monitoring has itself become a compliance institution in many banks and financial institutions, employing both specialist human capital ${ }^{55}$ and 'regtech' ${ }^{56}$ Hence, regulation of payment systems has extended to combating financial crime and anti-money laundering and such regulation, whether rightly or wrongly, has been designed to leverage upon the existing organisational systems of control within banks and financial institutions, in order to achieve efficiency and effectiveness in gatekeeping against abuse of payment or value transfer systems. ${ }^{57}$ Further, the scope of 'financial crime' is being extended with the criminalisation of tax evasion ${ }^{58}$ and bribery, ${ }^{59}$ further increasing the burdens placed on banks and financial institutions in their due diligence and internal control systems. In many jurisdictions' battle against tax evasion, we see financial institutions being specifically enrolled to become gatekeepers and informants, such as compliance with automatic information reporting regimes. In the US and to an extent in the $\mathrm{EU}$ (and transposed in the UK), automatic information reporting regimes require banks and financial institutions having customers whose origins are in the abovementioned jurisdictions to report their identities and relevant assets for taxation purposes ${ }^{60}$ The scope of assets covered in the US legislation FATCA is very wide, but the EU legislation ${ }^{61}$ is limited to savings income. These regulatory obligations are on the one hand changing the nature of commercial services that banks provide, but on the other hand reinforce the institution of the network or coterie of peer clearing entities as they are entrusted with specific public interest responsibilities in gatekeeping or informing. ${ }^{62}$

The institutions of the large value payment systems are ultimately anchored in the needs to supervise money flows and to ensure that legitimate transfers achieve settlement and finality,

\footnotetext{
${ }^{51}$ Directive 2005/60/EC of the European Parliament and of the Council of 26 October 2005, amended as of Directive (EU) 2015/849 of the European Parliament and of the Council of 20 May 2015 on the prevention of the use of the financial system for the purposes of money laundering or terrorist financing.

${ }^{52}$ Above and the guidelines developed as best practices for banks by the Joint Money-Laundering Steering Group, an association formed by financial institutions, see http://www.jmlsg.org.uk/.

${ }^{53}$ FCA Handbook SYSC 6 and the Joint Money-Laundering Steering Group Guidelines, above.

${ }^{54}$ Section 330 of the UK Proceeds of Crime Act 2002 for example, based on the 40 Recommendations issued by the Financial Action Task Force (available on http://www.fatfgafi.org/pages/0,2987, en 322503793223572011111 1,00.html) on the institution of financial intelligence units to receive suspicious transactions reporting in order to monitor the passage of proceeds of crime.

${ }^{55}$ Annie Mills, Essential Strategies for Financial Services Compliance (Chicester: John Wiley \& Sons, 2008).

${ }^{56}$ Smart technology is increasingly being deployed to detect suspicious transactions or to improve on customer due diligence procedures, see 'The Role Of Technology In Regulatory Compliance', Forbes.com (11 July 2016).

${ }^{57}$ See SYSC 3.2, FCA Handbook.

${ }^{58}$ See for eg the UK's criminalisation of tax evasion by companies, see Criminal Finances Act 2017.

${ }^{59}$ UK Bribery Act 2010.

${ }^{60}$ See discussion in Iris H-Y Chiu, 'From Multilateral to Unilateral Lines of Attack: The Sustainability of Offshore Tax Havens and Financial Centres in the International Legal Order" (2016) 31 Connecticut Journal of International Law 177.

${ }^{61}$ Council Directive 2011/16/EU of 15 February 2011 on administrative cooperation in the field of taxation and repealing Directive 77/799/EEC.

${ }^{62}$ For example the requirements under $\mathrm{s} 330$ of the UK Proceeds of Crime Act requiring authorised disclosures to be made in relation to suspect transfers.
} 
meeting both commercial objectives and public policy goals. These are achieved by the network of peer clearing entities entitled to central bank support and supervised by the central bank. These institutions are arguably in a 'settled' state in the UK, and also in the EU and US.

Next, we posit that where large value transfers involve cross-border payments outside of the euroarea or not in US dollars, the institutionalisation of international level payment systems follow a similar path as that adopted in national systems, also featuring the crucial tenets of peer clearing status for intermediaries involved, underlined by central bank support and approximating the status of public international infrastructure.

\section{International Large Value Payments}

International payments involving foreign currency are often made via correspondent banking networks. In this payment transaction, the payor's bank may maintain an account of deposits with a range of banks in other countries. If a payor customer instructs a payment instruction to be paid out in a foreign jurisdiction, usually in that jurisdiction's currency, the payor's bank would instruct its relevant correspondent bank to make payment to the ultimate payee or payee's bank.

Correspondent banking is based on bilateral trust and mutual respect for each other, and the services are often reciprocal in nature. ${ }^{63}$ As will be discussed shortly, the transfer of international retail payments may involve other institutions such as local shop agents (for Western Union) or postoffices (Euro-giro), but based on the same principle of having bilateral or network relationships with similar or peer outfits in foreign jurisdictions in order to coordinate the transfer. Large value international payments still tend to be routed through bank-based relationships, and this could be due to the perception of safety and security with using banks as financial institutions having peer status, in no small part due to the regulated nature of such financial institutions. ${ }^{64}$

The bilateral relationships described above do not necessarily make for a fast large value transfer, and risks remain in relation to counterparty intermediaries' solvency. The equivalent of a national real-time gross settlement system at the international level can now be found in the form of the Continuous Linked Settlement (CLS) services. CLS Group is a private corporate group with international subsidiaries and is subject to oversight by the Federal Reserve Bank of New York. One of its subsidiaries the CLS Bank has attained equivalent status as a bank but focuses only on international currency transfer and settlement. CLS maintains central bank accounts in all of the currencies it offers settlement, and is able to achieve a real-time payment versus payment settlement standard. This means that transfer orders routed to CLS are settled by CLS by debiting its account with the relevant central bank in which the payor's currency is denominated, and crediting its account with the central bank account in which the payee's currency is denominated ${ }^{65}$ This settlement achieves both efficiency and finality, meeting users' ultimate needs. However, the efficient business model of the CLS cannot be achieved otherwise than by central bank support in all of the currencies it offers settlement, and such central bank recognition can only be earned through subjection to regulation and oversight for the public infrastructure nature of CLS' functions. It is thus

\footnotetext{
${ }^{63}$ Committee on Payments and Market Infrastructures, Bank for International Settlements, 'Correspondent Banking' (July 2016) at http://www.bis.org/cpmi/publ/d147.pdf.

${ }^{64}$ On how bank regulation has underpinned the dominance of bank-led payment systems, see Dan Awrey and Kristin van Zwieten, 'Law and the Shadow Payment System' (2016) at http://ssrn.com/abstract=2843772.

${ }^{65}$ Carol Clark, Victor Lubasi and Gozde Yazar, 'Global Payment Systems' (2005-6) 1 Journal of Payment Systems Law 25.
} 
subject to the oversight of the Federal Reserve Bank of New York which designates the CLS as being a systemically important financial market infrastructure. ${ }^{66}$ As a regulated financial institution, the CLS is also subject to anti-money laundering and terrorist financing regulation in the US as well as the FATCA. CLS currently processes almost over half of all international large value transfers.

Even for controlled currencies such as the Chinese renminbi, international large value transfers are cleared and settled based on the same institutional concepts of clearing banks recognised as having peer status and central bank support for settlement finality. Settlement finality of the renminbi is achieved via the crediting and debiting of accounts held by recognised clearing banks in the People's Bank of China, the Chinese central bank. The renminbi is a controlled currency but there is growing international need for it to be used for international payments. ${ }^{67}$ Hence the People's Bank of China has achieved a compromise by recognising a select coterie of clearing banks in offshore jurisdictions for renminbi transfers, usually a foreign branch of one of its large four state-controlled commercial banks, the Bank of China, the Chinese Construction Bank, the Industrial and Commercial Bank of China or Agricultural Bank of China. ${ }^{68}$ Foreign banks are able to provide offshore renminbi services for their customers based on bilateral accounts with the designated offshore Chinese clearing bank branches. Hong Kong enjoys a special status as an international renminbi business hub as its clearing banks that enjoy access to the Hong Kong Monetary Authority's RTGS system is able to link up with the Chinese high value RTGS system maintained by the People's Bank of China. This makes Hong Kong a choice location for the clearing and settlement of renminbi transactions. ${ }^{69}$

The key institutional features of large value payment systems are arguably in a 'settled state'. This may however be regarded as insufficiently competitive, and arguably this is reflected in relatively high user charges that are paid for clearing and settling large value transfers. ${ }^{70}$ Is competition the answer to disrupt the apparent complacency observed? In Section B, we discuss the advent of distributed ledger technologies that may reform clearing and settlement as practised. However a note of caution is warranted: competition may drive efficiency improvements where there is slack. In the large value transfer systems discussed above, there is little slack, due to central bank support for the RTGS. Further the cost of using the large value transfer system reflects the cost needed to secure central bank support and meeting regulatory compliance, all of which can be regarded as 'correctly' priced. In an arguably limited space, competitors also need to meet the multi-faceted objectives in both commercial and public policy served by the large value payment system. The institutional analysis above is not intended to dismiss the utility of introducing competition into large value payment systems but is necessary to put into perspective the salience of competition in this

\footnotetext{
${ }^{66}$ See https://www.cls-group.com/About/CG/Pages/default.aspx.

${ }^{67}$ Domestic importers may wish to avoid the costs of using a foreign currency while foreign counterparties increasingly warm to holding renminbi accounts due to increasing trade activities and relations with Chinese counterparties. See Shen Wei, 'Cross-border Trade Settlement in Renminbi: Risks, Implications and Prospects' (2013) 11 Journal of International Banking Law and Regulation 448.

${ }^{68}$ However the system used for clearing and settlement at the People's Bank of China level is the deferred net settlement system which settles multiple times within the day therefore mitigating settlement risk to an extent, see 'CIPS- China's Net Hybrid Settlement System' at https://www.treasurymanagement.com/showarticle.php?pubid=1\&issueid=355\&article=2929\&page=showarticle .

${ }^{69}$ See HK Monetary Authority, 'The Global Offshore Renminbi Business Hb' (2015) at http://www.hkma.gov.hk/media/eng/doc/key-functions/monetary-stability/rmb-business-in-hongkong/hkma-rmb-booklet.pdf.

${ }^{70}$ For example, a user is typically charged $£ 35$ for using CHAPS in the UK.
} 
complex area where multi-faceted objectives need to be achieved and have indeed been achieved to a large extent.

We turn now to retail payment systems.

\section{Retail Payment Systems}

A key difference in the institutions for large value payment systems and retail payment systems is the role of central bank support, which is less prominent in the latter. This is because retail payment amounts are generally low value although high volumes of payment may be processed. It may be too costly for central banks to be involved in mitigating settlement risk, such as by providing the RTGS. Retail payment systems are a collective infrastructure that has arisen from the Coasean coordination of peer clearing banks. This has evolved from banks being the main providers of current accounts and payment services, core business functions recognised early on in judicial opinion. ${ }^{71}$ Retail payments are cleared between banks and ultimately settled across banks' accounts held at the central bank. As discussed above, the central bank provides the ultimate settlement asset for retail payments too. However there has not been such a strong compulsion towards the RTGS in retail payments unlike central bank policy in large value transfer systems.

The relatively less involvement by the central bank in policy setting for the mechanics of clearing and settlement results in the dominance of commercial policy in retail payment systems, usually favouring the interests of clearing banks. Hence, service standards experienced by users are not the most competitive, in terms of cost, timeframe for finality to be achieved and consumer protection. ${ }^{72}$ We may consider this space to be ripe for competitive disruption. In jurisdictions such as the UK, EU and US, a certain level of institutional maturity in retail payment systems has been attained as a result of regulatory intervention that seek to protect the public interest in consumer protection as well as the public infrastructure aspects of these systems. Regulation has adopted pro-competition features as well as prescribed minimum standards as 'public goods', and these two strategies could conflict at certain levels. Hence, market-based governance (in the form of competition) and the consumer protection objectives of public interest are key institutional features of retail payment systems in the UK, EU and US. In emerging economies such as China where regulatory governance is in earlier stages of development, retail payments are a fiercely competitive and growing market. ${ }^{73}$ However, the same consumer protection and public infrastructure needs remain salient.

\section{Market Failures of Retail Payment Systems}

In the UK, the system that is most widely used to support clearing and settlement of retail payments is BACS (Bankers' Automated Clearing Services), which together with CHAPS is owned by the UK Payment Administration, formerly the Association of Payments and Clearing Services. BACS is a deferred net settlement system, with settlement taking place end of day across clearing entities' accounts at the central bank. This is very similar to the service standards provided by CHIPS, the

\footnotetext{
${ }^{71}$ See United Dominions Trust Ltd v Kirkwood [1966] 2 QB 431.

${ }^{72}$ Eg in the UK see the Cruickshank report, D Cruickshank, Competition in UK Banking: A Report to the Chancellor of the Exchequer (March 2000).

${ }^{73}$ Douglas Arner, Jànos Barberis and Ross Buckley, 'The Evolution of Fintech; A New Post-Crisis Paradigm?'

(2016) at http://www.ssrn.com/link/UNSW-LEG.html.
} 
largest US retail payment clearing and settlement system, also on a deferred net settlement basis. ${ }^{74}$ So typically a BACS payment in the UK may only be received in the payee's account after 2-3 working days. Consumers run the risk of default of their payor or intermediaries during the clearing period. Further, the domination by the coterie of peer clearing banks in the payment system has not resulted in advancement in service and protection standards for consumers without regulatory intervention. Sans regulation, consumers may be subject to terms and conditions that are rather sharp, especially in terms of fees and charges, such as keen overdraft charges for inadvertent overdrafts. This is an area where courts have been unable to help consumers as the scope of general protection against unfair consumer terms does not include 'price' or consideration, of which bank charges are a part. ${ }^{75}$ Consumers also typically bear the risk of fraud or mistake in payments, as courts are unwilling to hold banks liable for fraudulent payments unless the bank has been put on reasonable enquiry. ${ }^{76}$ The overall lack of payment competition and innovation was lamented in the UK's Cruickshank report in 2000. ${ }^{77}$ The lack of competitiveness in bank-led retail payments services is not unique to the UK, as it is observed in the US how money market funds began to challenge banks in offering cheque and transaction services to their investors. ${ }^{78}$ The retail payment services competition in China is also due to the lack of competitive services provided by the incumbent banking sector. ${ }^{79}$

One may think of credit cards as being disruptive innovations that have changed the landscape of payments- that cards rather than bank payments are used more than ever to transfer value in a retail context. ${ }^{80}$ However, the leading credit card providers VISA and Mastercard are both consortia owned by banks that carry out clearing and settlement of card payments in-house. ${ }^{81}$ There is extensive critique regarding the fees charged by these card providers to merchants for the 'interchange fees' incurred between banks as they clear and settle customers' payments to merchants.$^{82} \mathrm{~A}$ similar situation exists in China where Unionpay, a consortium owned by the

\footnotetext{
${ }^{74} \mathrm{http} / / /$ www.bankofengland.co.uk/markets/Pages/paymentsystem/deferred.aspx.

${ }^{75}$ Office of Fair Trading v Abbey National plc and Others [2009] UKSC 6.

${ }^{76}$ Barclays Bank v Quincecare Ltd [1992] 4 All ER 363; Lipkin Gorman v Karpnale Ltd [1989] 1 WLR 1340.

77 D Cruickshank, Competition in UK Banking: A Report to the Chancellor of the Exchequer (March 2000).

${ }^{78}$ The banking characteristics of the money market fund, which is a collective investment vehicle holding short term highly illquid and safe assets that allows on-demand access by investors, was patented by Bruce R Bent, the inventor of the first of such funds, the Reserve Primary Fund. See

https://www.google.com/patents/US6374231 for the patent filed by Bent, and an introduction to money market funds in Matthew P Fink, 'Historical Rationale for US Money Market Funds', in Viktoria Baklanova and Joseph Tanega (eds), Money Market Funds (Oxford: Oxford University Press 2013) at chapter 4; Viktoria Baklanova, 'Money Market Funds- An Introduction to the Literature' (January 2010) at https://www.law.berkeley.edu/files/bclbe/Intro_MMF_Literature.pdf.

${ }^{79}$ Douglas Arner, Jànos Barberis and Ross Buckley, 'The Evolution of Fintech; A New Post-Crisis Paradigm?' (2016) at http://www.ssrn.com/link/UNSW-LEG.html.

${ }^{80} \mathrm{Hal}$ Scott, 'The Importance of the Retail Payment System' (2014) at http://ssrn.com/abstract=2539150 (research supported by Mastercard); Wilko Bolt, 'Retail Payment Systems: Competition, Innovation and Implications' (2012) at http://ssrn.com/abstract=2192046.

${ }^{81}$ Carol Clark, Victor Lubasi and Gozde Yazar, 'Global Payment Systems' (2005-6) 1 Journal of Payment Systems Law 25.

${ }^{82}$ Adam J Levitin, 'Payment Wars: The Merchant-Bank Struggle for Control of Payment Systems' (2007) at http://ssrn.com/abstract=981637; Agnieszka Janczuk-Gorywoda, 'Evolution of EU Retail Payments Law' (2015) at http://ssrn.com/abstract=2694426; Wilko Bolt, 'Retail Payment Systems: Competition, Innovation and Implications' (2012) at http://ssrn.com/abstract=2192046 but see defense in Oliver Ireland and Rachel Howell, 'The Evolving Payments Landscape' (2005-6) 1 Journal of Payment Systems Law 524.
} 
incumbent banking sector dominates credit and debit card transactions. ${ }^{83}$ High levels of interchange fees are regarded as a manifestation of the uncompetitive landscape and in some jurisdictions, regulatory intervention has taken place to keep the fees under control. ${ }^{84}$

It may be argued that alternative systems have arisen in competition against bank-led retail payment systems worldwide. For example, mobile payments, Western Union, Euro-giro, Paypal and Alipay. These innovations to an extent challenge uncompetitive commercial policy offered by the incumbent banking sector and offers new efficiencies for the customer interface. However these efficiencies should not be achieved at the expense of less consumer protection. Further, many of these innovations do not fully penetrate the clearing and settlement system which is dominated by the coterie of peer clearing banks. ${ }^{85}$ We are of the view that only M-PESA in Kenya is a true alternative to a bank-led retail payments system as it fully penetrates the payment process from initiation to clearing and settlement. Paypal and Alipay, discussed in Section B, to an extent create alternative payment systems, but Western Union and Euro-giro do not function independently of banks. Section $B$ takes these discussions in further detail but we will explain why M-PESA is unique.

In mobile payment systems such as M-PESA which is prevalent in Kenya, pre-paid mobile accounts are used like current accounts, and the mobile phone operator Safari.com facilitates small consumer payments from one account to another using the mobile number as identifier for payment instruction. ${ }^{86}$ This alternative system requires mobile phone networks to clear and settle payments, which has worked in M-PESA because of the largely unbanked nature of the population and the less restrictive regulations applicable to mobile phone operators. This system has not taken off in more developed and banked jurisdictions ${ }^{87}$ as the regulatory costs for mobile phone operators to maintain a settlement and finality architecture would be substantial. ${ }^{88}$ Mobile phone network operators would also need to provide for a trustworthy alternative settlement system outside of the bank-led clearing and settlement system, in order to assure customers that payment would be made and settled without running the risk of the operator's potential insolvency. For example, M-PESA institutes a trust framework at its holding company level to ringfence customers' funds in order to provide a resilient and trustworthy service. They are able to do so as having economies of scale as a virtual monopoly ${ }^{89}$ as mobile service provider in Kenya. ${ }^{90}$

\footnotetext{
83 'Ant's Alipay Challenges Unionpay's Dominance', Financial Times (30 July 2016).

${ }^{84}$ To be discussed shortly in our review and evaluation of regulatory intervention.

${ }^{85}$ Robleh Ali, James Barrdear, Roger Clews and James Southgate, 'Innovations in Payment Technologies and the Emergence of Digital Currencies' (Bank of England Quarterly Bulletin 2014), Jean-Michel Sahut, 'Internet Payment and Banks' (2008) 13 International Journal of Business at https://papers.ssrn.com/sol3/papers.cfm?abstract_id=1755495; Jane Kaufman Winn, 'Clash of the Titans: Regulating the Competition between Established and Emerging Electronic Payment Systems' (1999)14 Berkeley Tech. L.J. 675 whose piece although rather early, also predicts that payment innovation will not change the incumbent landscape by much. All to be discussed shortly.

${ }^{86}$ Ignacio Mas and Dan Radcliffe, 'Scaling Mobile Money' (2011) at http://ssrn.com/abstract=1681245.

${ }^{87}$ Malte Krueger, 'Mobile Payments: The Second Wave' in Jakub Górka (ed), Transforming Payment Systems in Europe (Basingstoke: Palgrave Macmillan 2016).

${ }^{88}$ David B Humphrey, Setsuya Sato, Masayoshi Tsurumi and Jukka M Vesala, 'The Evolution of Payments in Europe, Japan and the US' (World Bank Policy Research Paper 1996); Marc Bourreau and Marianne Verdier, 'Cooperation for Innovation in Payment Systems: The Case of Mobile Payments' (2010) at http://ssrn.com/abstract=1575036.

89 Discussed in https://www.pressreader.com/kenya/nairobi-law-monthly/20160201/281998966502886.
} 
In jurisdictions where banks have already built a collective infrastructure for clearing and settlement, there is a lack of incentive for alternative equivalent systems to arise due to the inefficiencies of high set-up cost and duplication. Competing retail payment services do not compete on the basis of offering a fully penetrating payment system but only in certain aspects of the payment process. This may not necessarily be seen as a market failure. The need for settlement and finality in retail payments is achieved by a network of peer clearing entities using central bank settlement. There are efficiencies in leveraging upon the current bank-based clearing and settlement system because of its already existent network effects, and because ultimate settlement of sovereign-backed currency in accounts held by the central bank is fundamental to social confidence and trust. ${ }^{91}$ Moreover, bankled retail payment systems secure public interest objectives in stability and anti-abuse, as they are subject to regulation as critical infrastructure and in anti money-laundering, just as discussed earlier. The most significant volumes of consumer payment remain routed through clearing and settlement systems that are led by banks.

Nevertheless where the uncompetitive aspects of payment services provided by banks are concerned, EU policy makers have taken a pro-competition stance while recognising that other public policy objectives also have to be met. A mixed approach of prescribing minimum standards and facilitating competition is observed in EU regulation also fully transposed in the UK. However, facilitating competition is not easy given the incumbents' vested interests and their powerful network effects, not to mention that the stability of these network effects is relevant to public policy objectives of financial stability and market confidence. In jurisdictions such as China where regulatory governance in retail payments is still developing, competition can achieve great strides in the consumer experience, but we believe that public interest issues relating to consumer protection and the needs of the public infrastructure will have to be reckoned with in policy-making.

Consumer protection regulation is a growing institutional feature in retail payment systems as it achieves clarity in the allocation of responsibility and risks, a necessary quality of the consumer experience of trust. ${ }^{92}$ Consumer protection is arguably graduating to its place as a public good, ${ }^{93}$ and the experience of more mature retail payment systems like the UK, EU and US is to provide extensively for the key tenets of consumer protection via regulation, while facilitating competition where it matters ${ }^{94}$ This trajectory provides lessons for emerging jurisdictions like China where retail payment innovation is growing at a heady pace. However, we see settlement and finality remaining firmly in the hands of the payment architecture fostered by peer clearing entities enjoying central bank support in terms of the settlement asset.

\section{The Development of Consumer Protection Policy: Co-regulation between Public Policy-Makers and Industry}

\footnotetext{
90 See discussion in Dan Awrey and Kristin van Zwieten, 'Law and the Shadow Payment System' (2016) at http://ssrn.com/abstract=2843772.

${ }^{91}$ Stefan W. Schmitz, 'The Political Economy of Institutional Change in the Payment System and Monetary Policy' (2006) at http://ssrn.com/abstract=944404.

92 L Ali Khan, 'A Theoretical Analysis of Payment Systems' (2008) 60 South Carolina Law Review 1.

${ }^{93}$ Agnieszka Janczuk-Gorywoda, 'Evolution of EU Retail Payments Law' (2015) at http://ssrn.com/abstract=2694426.

${ }^{94}$ Discussed below.
} 
In the EU and UK, policy-makers have engaged in persuading the network or coterie of peer clearing entities in retail payment systems to improve on efficiencies, user choice and experience. In the UK the Payment Systems Task Force was set up in 2003 to develop national plans for the UK's retail payment systems. This task force consisted of industry representatives, independent members and a Bank of England observer, and in 2007 became the UK Payments Council, a self-regulatory organisation to recommend policies on retail payment systems but with no formal enforcement powers over its industry members. The Council had mandates to take into account stakeholder opinion and reports to the public by publishing an annual National Payments Plan. It was also anchored in public policy objectives in developing the UK's retail payment systems. One of the achievements of the Council was the introduction of the Faster Payment system, so that retail payments between certain clearing banks can be cleared and settled in real-time, riding on the back of the technological systems already in place to support the RTGS in large value transfers. However when the Council proposed to abolish the cheque as a form of retail payment in 2010, public outcry ensued. This ultimately led to an independent review of the Council which criticised its governance as being dominated by the banking industry. The Council's policy-making powers have thus been minimised with the establishment of the Payment Services Regulator under the UK Financial Conduct Authority. ${ }^{95}$

In the EU, policy-makers have been encouraging the industry to move towards a Single European Payments Area (SEPA), ${ }^{96}$ in order to achieve efficient standards in payment services and harmonisation in consumer protection. Efficiencies and ease in payment services would greatly boost intra-EU economic commerce and growth. ${ }^{97}$ Persuading the industry to lower the cost for cross-border payments in euro was unsuccessful shortly after the 1999 adoption of the euro, and policy makers therefore legislated in $2001^{98}$ that euro payments made cross-border could only be charged at the same rate as domestic payments. This caused the banking industry to suffer losses in relation to cross-border payments and they formed the European Payments Council as an industry representative body in order to lobby payments policy in the EU. One of the achievements of the European Payments Council, in responding to the SEPA vision, is the standardisation of payment instructions in order to facilitate efficient payment. The introduction of the 'International Bank Account Number' and 'Branch Identifier Code' for use in all payments in the euro-area has been regarded as a successful measure. Further, the European Payments Council has been developing interoperability schemes for credit transfers and direct debits. ${ }^{99}$

The incremental approach to policy achievements by self-regulatory bodies in the UK and EU reflects industry inertia in incurring cost to provide the public goods aspects of a retail payment infrastructure. In order to establish both commercially-driven and public policy-based institutions in retail payment systems, it would not be possible to rely only on industry-led initiatives. We think the

\footnotetext{
${ }^{95}$ The FCA has responsibility for administering the Payment Services Directive 2 that was passed in 2015. See discussion in Bruce J Summers and Kirstin E Wells, 'Governance of Payment Systems: A Theoretical Framework and Cross-Country Comparison' (2014) at http://ssrn.com/abstract=2476552.

${ }^{96}$ Now enshrined in the SEPA regulation (EU) No 260/2012.

${ }^{97}$ Stephen Millard and Matthew Willison, 'The Welfare Benefits of Stable and Efficient Payment Systems' (2006) at http://papers.ssrn.com/sol3/papers.cfm?abstract_id=932583.

${ }^{98}$ Regulation (EC) No 2560/2001 of the European Parliament and of the Council of 19 December 2001 on crossborder payments in euro.

${ }_{99}$ Discussed in Jane K. Winn, 'Governance of Global Mobile Money Networks: The Role of Technical Standards' (2013) 8 Wash. J.L. Tech. \& Arts 197-244.
} 
experience of limitations in co-regulation is not likely confined to the EU and UK as the commercial objectives of payment services providers do not neatly coincide with more costly consumer protections and public interest needs. In emerging jurisdictions like China, it may be a matter of time before more regulatory governance is introduced to secure consumer protection needs, and this would invariably affect the liberal landscape for competition. ${ }^{100}$ The introduction of the Payment Services Directive in 2007 and in 2015, together with a suite of other regulations, establishes the public good of consumer protection in retail payment systems in the UK and EU. The pursuit of the public good of consumer protection has brought about two key developments that we see as likely to persist. One is that commercial flexibility and choice ${ }^{101}$ promoted by regulation is in a limited space for competition in retail payments, and the second is that settlement and finality is likely to remain controlled by architecture dominated by the network of peer clearing entities enjoying central bank support.

\section{Regulation in Retail Payment Systems and the Institution of a Public Infrastructure}

Due to contracting inequality and agency problems between consumers and payment providers, the allocation of responsibilities and risk may not optimally be left to private contract. ${ }^{102}$ Regulation can be well-placed to deal with guarantees of minimum service standards, responsibilities on the part of payor and payment provider, risk allocation between them and liability issues, consumer protection and price control, all aspects susceptible to market failure. Indeed, the regulatory regime in the EU's Payment Services Directive 2007 (transposed in the UK Payment Services Regulations 2009) and the subsequent recast Directive 2015 provide a comprehensive regime that deal with all of the abovementioned aspects. ${ }^{103}$ The UK's Consumer Credit Act 1974 also provides for consumer protection in governing credit card providers. Two governance strategies are adopted in regulationone to prescribe standards to correct market failure which have raced to the bottom, and two, to facilitate competition. It may be argued that the two strategies conflict as minimum standards could deter entry. However, limited entry reflects the public good premises in retail payment regulation. Section B will show that the space for competition in payment services does not extend to fully penetrating the entire payment system. Nevertheless, such competition could still serve socially beneficial purposes.

\footnotetext{
${ }^{100}$ Consumer protection is in its infancy in China. At the moment a department was set up in 2011 in the People's Bank of China to administer consumer protection such as to enforce reversal of mistaken or fraudulent payments. It is regarded as a pilot project pending further formalisation, see http://www.worldbank.org/en/news/feature/2013/02/05/Beijing-Workshop-Promotes-Financial-ConsumerProtection-in-China.

${ }^{101}$ Robert G Ballen and Thomas A Fox, 'The Role of Private Sector Payment Rules and a Proposed Approach for Evaluating Future Changes to Payments Law' (2008) 83 Chicago-Kent Law Review 937.

${ }^{102}$ See arguments such as in the US calling for a unified payments law in view of the inefficiencies and uncertainties dealing with risk allocation and consumer protection, pre-dating Article 4A of the Uniform Commercial Code on Funds Transfer, see Peter A Alces, 'A Jurisprudential Perspective for the True Codification of Payments Law' (1984-5) 53 Fordham Law Review 83; Steven L Harris, 'Introduction to Rethinking Payments Law' (2008) 83 Chicago-Kent Law Review 377; Stephanie Heller, 'A Proposal for Consideration of a Unified Payments Law' (2008) 83 Chicago-Kent Law Review 485; James Steven Rogers, 'Unification of Payments Law and the Problem of Insolvency Risk in Payment Systems' (2008) 83 Chicago-Kent Law Review 689. 103 Dermot Turing and Simon Crown, '21st Century Payments In Europe: The Payment Services Directive' (2006-7) 2 Journal of Payment Systems Law 639.
} 
First, regulation provides a regime for all payment services providers, so that payment service is not the exclusive preserve of banks. The de-coupling of regulating payments and banks ${ }^{104}$ paves the way for the development of competition in the payment service provision landscape. As long as a payment service provider ('provider') can meet the criteria required for authorisation, which relates to registered office, effective governance, internal control, the fitness and propriety of management and the meeting of relevant capital adequacy requirements, ${ }^{105}$ the provider need not be a bank. ${ }^{106}$ This however also means that all payment services providers have to meet certain obligations for consumer protection, so that innovation is not allowed at the expense of lower consumer protection.

The EU's Payment Services Directive 2 expressly adopts the 'modularisation' of payment services. The Directive allows providers of different types to be authorised, such as payment initiation services (PISP), accounts information services (AISP) and accounts servicing payment services providers (ASPSP). The PISP deals with customer interfaces for payment, such as mobile payments, Apple pay etc, to be discussed in the next Section, while AISP deals with consolidation of financial accounts information for easier management by consumers. The ASPSP is where customers maintain their payment account, usually at a bank, and the Directive mandates that the ASPSP must allow access by the customer's PISP (where an electronic interface is used) so that customer choice in initiating payment is not obstructed. ${ }^{107}$ It is envisaged that the PISP may be able to confirm the customer's availability of funds and such a 'clearing' role is not limited to the ASPSP. ${ }^{108}$ Similarly access by the AISP to the customers ASPSP must be allowed if customers have consented to such. ${ }^{109}$ Further, the FCA also maintains a register of exempt small payment institutions. ${ }^{110}$ The modularisation of payment services legitimises competition and removes certain barriers to entry erected by banks, but also delimits the scope of competition, which may explain why it is unlikely that competition will penetrate to the levels of clearing and settlement. However, those levels of competition may be sufficient to improve user experience and cost to a significant extent.

Next, regulation provides a framework for allocating responsibilities to consumer and provider, which takes into account the needs of consumer protection. Consumers need to provide a clear payment mandate, by utilising personalised security features. In this respect providers are responsible to ensure that strong customer authentication and secure communications can be achieved. ${ }^{111}$ This is supported by comprehensive information provision duties on the part of the

\footnotetext{
${ }^{104}$ Ross T Buckley and Ignacio Mas, 'The Coming of Age of Digital Payments as a Field of Expertise' (2016) Journal of Law, Technology and Policy 71.

105 which are calibrated for payment business and not the same as applicable to banks.

106 Regulations 5, 6, 18, UK Payment Services Regulations 2009, likely to be amended to include more comprehensive criteria such as a 3-year business plan and evidence of business continuity, customer data protection and customer dispute resolution plans, see Art 5, Payment Services Directive 2015, Directive (EU) 2015/2366 of the European Parliament and of the Council of 25 November 2015 on payment services in the internal market, amending Directives 2002/65/EC, 2009/110/EC and 2013/36/EU and Regulation (EU) No 1093/2010, and repealing Directive 2007/64/EC.

107 Art 37, 66, Payment Services Directive 2 (2015).

108 Art 65, Payment Services Directive 2 (2015).

${ }^{109}$ Art 67, Payment Services Directive 2 (2015).

${ }^{110}$ Subject to the condition that they have not been convicted of money laundering or terrorist financing offences, Regs 12, 13, Payment Services Regulations 2009.

${ }^{111}$ Articles 69, 70, Payment Services Directive 2 (2015).
} 
provider. ${ }^{112}$ Consumers are obliged to notify the provider in the event of unauthorised use of payment instruments, but in the absence of fraud or gross negligence, would only be responsible for up to 50 euros of loss, meaning that such a risk allocation would hold in the event of the consumer's simple negligence. ${ }^{113}$ However it is to be noted that where credit card transactions in the UK are concerned, consumers' liability is limited to $f 50$ where there may be misuse of credit card instruments by another person following the cardholder's loss of the card. There is no provision for the limitation of liability to be waived for gross negligence. ${ }^{114}$ Further, credit card providers are jointly and severally liable with the supplier of goods or services paid for with the credit card, in the event of the supplier's breach for transactions exceeding $£ 100$ but below $£ 30,000 .{ }^{115}$

Consumers are responsible for supplying the correct unique identifiers of the payee's payment services account. ${ }^{116}$ Where the payment instrument is apparently validly executed, if the consumer denies having made authorisation for use, the burden of proof is on the provider to show that the payment was authenticated, recorded and executed correctly. ${ }^{117}$ The provider is responsible for correct execution of a valid payment mandate, and failure to do so would result in liability to refund the payor and restore any charges associated with the payment, as well as to trace the defective payment. The payee's provider is also liable to credit funds intended for the payee if there is failure to do so upon clearing a valid incoming payment. ${ }^{118}$ The regime for risk and responsibility allocation under this regime is generally appraised to be adequately protective of consumers, although it remains open what 'gross negligence ${ }^{119}$ amounts to in using payment instruments. ${ }^{120}$ In the US, Khan argues for the need for a coherent payments law that deals with payment responsibilities and liabilities in authorisation, negligence and dishonour. ${ }^{121}$ The allocation of risk and responsibility is a governance order that is unlikely to be provided by market forces in an optimal manner consistent with consumer protection, and may be regarded as a public good. This position is reflected in payment legislation at the federal level as well as Art 4A of the Uniform Commercial Code. ${ }^{122}$

Further, regulation provides for standardisation of service standards so that consumers are not left to the inefficiencies of commercial policy against them. For example, EU regulation provides that payment charges are to be transparent and to be allocated in such a way that the payee should not

112 Regs 36-50, 55-58, Payment Services Regulations 2009, largely similar to the Payment Services Directive 2 (2015).

${ }^{113}$ Regs 57-59, 61-64, Payment Services Regulations 2009, the original threshold is $f 50$, but will be lowered to 50 euros by the implementation of the Payment Services Directive 2 (2015) (Art 74).

${ }^{114}$ Section 84, Consumer Credit Act 1974 amended by regulations in 1998.

115 Section 75, Consumer Credit Act 1974 , amended by regulations in 1983.

${ }^{116}$ Reg 74, Payment Services Regulations 2009, largely similar to the equivalent provisions in Payment Services Directive 2 (2015).

${ }^{117}$ Reg 72, Payment Services Directive 2 (2015).

${ }^{118}$ Regs 75-77, Payment Services Regulations 2009, largely similar to the equivalent provisions in Payment Services Directive 2 (2015), except that the liability to refund is made more immediate in the 2015 Directive, to be by the following business day.

119 The case of ICDL Saudi Arabia v. European Computer Driving Licence Foundation Limited [2011] IEHC 343; [2012] IESC 55 refers to a significant degree of carelessness, or that one falls short of the standard of care by a significant margin.

${ }^{120}$ Sideek M. Seyad, 'A Critical Assessment of the Payment Services Directive' (2008) 23 JIBLR 218.

${ }^{121}$ L Ali Khan, 'A Theoretical Analysis of Payment Systems' (2008) 60 South Carolina Law Review 1. These issues of responsibilities and risk allocation will be detailed shortly.

122 Regulation E, Electronic Funds Transfer Act and other legislation dealing with checks, cards and interchange fees, see https://www.federalreserve.gov/paymentsystems/other-regulations.htm. 
be debited a charge by their payment services provider. ${ }^{123}$ Regulation has also now been introduced to cap interchange fees for credit cards to $0.3 \%$ of the transaction, and to $0.2 \%$ of the transaction for debit cards. ${ }^{124}$ Further payment services providers must also meet the benchmark service standard of crediting the payee's payment services account within 1 business day from the receipt of the payment mandate, ${ }^{125}$ an improvement from the previous standard of 3 business days. ${ }^{126}$

Consumer protection is also at the centre of obligations imposed on payment services providers to secure their systems and protect their functions. ${ }^{127}$ Customer alternative dispute resolution services are to be made available by payment services providers as part of the regulatory duties imposed on them for complaints-handling. ${ }^{128}$ As consumer protection has become a public good, mandatory risk allocations and compliance with consumer protection obligations may mean increased cost for providers and such may affect the prospects of competition.

Finally, a 'public good' that European policy-makers desire to deliver is the integrated market supported by the SEPA. Hence, regulation has been introduced to make payment systems in member states 'reachable' and interoperable based on common standards and formats for credit transfers and direct debits. ${ }^{129}$ However, the promotion of interoperability of existing settlement systems is likely to produce a form of consolidation by incumbent bank-led clearing and settlement. ${ }^{130}$ On the one hand this could achieve economies of scale and efficiencies and promote the user experience, but on the other hand the trend towards consolidation or centralisation could also negatively impact upon the prospects of competition and the modularisation of payment services discussed above.

Retail payment systems have become highly regulated for public policy objectives in consumer protection. However the contest between supporting consumer choice and consumer protection means that: although the space for competitive improvement of the retail payment experience is overtly protected, it is at the same time a space that is delineated. Settlement and finality architecture remains largely impenetrable although the advent of distributed ledger technology may provide some challenge. We turn now to the role of disruptive payment innovation and competition.

\section{B. Payment Innovations and Impact}

\footnotetext{
${ }^{123}$ Arts 40, 42-49, 56-58, Payment Services Directive 2 (2015), and Art 62, 97. 98.

${ }^{124}$ Regulation (EU) 2015/751 of the European Parliament and of the Council of 29 April 2015 on interchange fees for card-based payment transactions, discussed in Nicole Jonker, 'Regulating Interchange Fees for Card Payments' in Jakub Górka (ed), Transforming Payment Systems in Europe (Basingstoke: Palgrave Macmillan 2016).

${ }^{125}$ Art 83, Payment Services Directive 2 (2015).

${ }^{126}$ Reg 70, Payment Services Regulations 2009.

127 Arts 94-98, Payment Services Directive 2 (2015) and section 5, Payments UK, Briefing on the Second

Payment Services Directive (July 2016) at

https://www.paymentsuk.org.uk/sites/default/files/PSD2\%20report\%20June\%202016.pdf.

${ }^{128}$ Arts 101-103, Payment Services Directive 2 (2015).

${ }^{129}$ Regulation (EU) No 260/2012 of the European Parliament and of the Council of 14 March 2012 establishing technical and business requirements for credit transfers and direct debits in euro and amending Regulation (EC) No 924/2009.

130 Jürgen Bolt and Udo Milkau, 'A Market for Payments: Payment Choice in the 21st Century Digital Economy' in Jakub Górka (ed), Transforming Payment Systems in Europe (Basingstoke: Palgrave Macmillan 2016).
} 
In this Section we discuss the three payment innovations relating to interfaces, virtual currency and distributed technologies. These three areas may be regarded as promising in terms of their competitive impact. We however take the view that competition, understood in the institutional perspective of payment systems, provides only a limited perspective to the disruptive nature of these innovations.

\section{New Payment Interfaces}

Payment innovation by banks has so far been incremental. Cheques remain a key payment instrument in the US, while debit and credit cards dominate in the EU. ${ }^{131}$ As Hirschmann ${ }^{132}$ has rightly pointed out, consumer preferences for payment interfaces may be influenced by many factors, such as perceived security and safety, the existence of rewards such as loyalty benefits, speed, or in some cases, personal fascination in engaging with certain interfaces, ${ }^{133}$ such as induced by technology-led payment innovations today.

Technological innovations in changing payment interfaces are on the rise. Although not exclusively so, many of these innovations have arisen to support online or e-commerce. ${ }^{134}$ Paypal arose to support individuals conducting commerce over ebay, so that buyers can pay their sellers using an email address. ${ }^{135}$ The Chinese equivalent of ebay which is Taobao, is supported by Alipay as commercial transactions grew in volume on Taobao. ${ }^{136}$ Amazon pay provides a system where consumers' payment information may be stored securely, and may be called up using '1-click'137 technology to pay for goods and services over Amazon.com, or at other merchants' websites.

In this landscape, many payment innovations relate to user interfaces in payment initiation. They provide competition at one level and do not penetrate to the levels of clearing and settlement. Paypal and Alipay may however present more substitutive challenges. For example, Amazon's 1-click offers innovation in storing customer's card information, and facilitating quick checkout. It does not offer a fully penetrating alternative clearing and settlement system. In terms of mobile phone-based payment interfaces, Apple pay allows users to initiate payment using a mobile phone interface, by storing customers' credit or debit card information in its digital wallet on its devices, which range

\footnotetext{
${ }^{131}$ David B Humphrey, Setsuya Sato, Masayoshi Tsurumi and Jukka M Vesala, 'The Evolution of Payments in Europe, Japan and the US' (World Bank Policy Research Paper 1996).

132 Elizabeth C. Hirschman, 'Consumer Payment Systems: The Relationship of Attribute Structure to Preference and Usage' (1982) 55 Journal of Business 531.

${ }^{133}$ Appealing to younger consumers, see David B Humphrey, Setsuya Sato, Masayoshi Tsurumi and Jukka M Vesala, 'The Evolution of Payments in Europe, Japan and the US' (World Bank Policy Research Paper 1996); David S. Evans, Karen Webster, Gloria Colgan and Scott Murray, 'Paying with Cash: A Multi-Country Analysis of the Past and Future of the Use of Cash for Payments by Consumers' (2013) at http://ssrn.com/abstract=2273192.

${ }^{134}$ See Jürgen Bolt and Udo Milkau, 'A Market for Payments: Payment Choice in the 21st Century Digital Economy' in Jakub Górka (ed), Transforming Payment Systems in Europe (Basingstoke: Palgrave Macmillan 2016)

135 Lawrence J Trautman, 'E-Commerce, Cyber, and Electronic Payment System Risks: Lessons from Paypal' (2016) 16 UC Davis Business Law Journal 261.

${ }^{136}$ Porter Erisman, Alibaba's World: How a Remarkable Chinese Company is Changing the Face of Global Business (2015) at ch11.

137 '1-click' allows consumers to check out quickly with the pre-stored payment information while not needing to re-enter or reveal such information.
} 
from the iphone, ipad and iwatch. ${ }^{138}$ Social media companies are also active in developing payment applications so that users can pay each other, effecting what seems like peer-to-peer payments outside of established bank networks. ${ }^{139}$ Wechat pay which is developed by Tencent in China allows users on Wechat's social media network to pay each other easily. However, these new payment interfaces are usually based on linking bank account information to the new interface in question, whether it is an Apple device or a social media account. Wechat pay works on the basis of users linking their Wechat accounts to their WeBank accounts. ${ }^{140} \mathrm{New}$ interfaces ultimately plug into the banking sector, in order to achieve the public good of settlement and finality necessary to sustain public trust in using those interfaces.

Innovation in payment interfaces draws much attention due to their integration with our favourite gadgets such as the smartphone or tablet. However such innovation is far from novel. For example in international payments, we see Western Union as a successful international retail payment system where agents in local corner shops are linked up to a common technological system to process receipt of customer's money, transfer and withdrawal by the payee. The appealing user interface in this case is that of the familiar local corner shop. However, the Western Union network in fact relies on clearing and settlement through banks and existing payment systems. It falls clearly short of providing an alternative banking service as senders can only initiate a Western Union payment with cash in hand and no credit can be drawn upon for payment services unlike with current accounts which have overdraft services. ${ }^{141}$

Although many new payment interfaces operate at only an initiation level, the competition they offer can improve user experience and efficiency, although the cost of bank-based clearing and settlement may not significantly change.

Other businesses have also forayed into the payments market where there may be a financial service element generated by business activities. For example, stored value cards that are used for public transportation services are turning into payment cards leveraging upon smart technology already in them. NETS flashpay or Octopus pay, public transport cards used in Singapore and Hong Kong ${ }^{142}$ are increasingly being used as payment cards for merchandise. Although at one level these new payment interfaces are not decoupled from the banking sector and have not, like M-PESA created an alternative payment system altogether, they have created opportunities for bank competition such as in Hong Kong. In the case of NETS flashpay in Singapore, the stored value cards are issued by the clearing banks in Singapore and approved for use to pay for public transport. The loading, use and transfer of stored value in these cards are actually linked to the existing bank-based clearing and

\footnotetext{
138 Mark Edwin Burge, 'Apple Pay, Bitcoin, and Consumers: The ABCs of Future Public Payments Law' (2016) 67 Hastings Law Journal 1493.

139 'China, Not Silicon Valley is Cutting Edge in Mobile Tech', New York Times (2 Aug 2016) at https://www.nytimes.com/2016/08/03/technology/china-mobile-tech-innovation-silicon-valley.html?_r=0.

${ }^{140}$ To an extent the establishment of WeBank is a breakthrough in competition for the Chinese banking sector, a possibility which is more remote in a more mature banking market in the EU or UK.

${ }^{141}$ Carol Clark, Victor Lubasi and Gozde Yazar, 'Global Payment Systems' (2005-6) 1 Journal of Payment Systems Law 25.

${ }^{142}$ Sujit Chakravorti and Carrie Jankowski, 'Forces Shaping the Payments Environment: A Summary of the Chicago Fed's 2005 Payments Conference' (2005-6) 1 Journal of Payment Systems Law 503.
} 
settlement architecture, ${ }^{143}$ although they offer a new interface for payment in competition with debit and credit cards. In the case of Octopus pay, the stored value cards are issued by a company Octopus Cards Limited which is a subsidiary of a bank holding company initially incorporated by all the major transport operators in Hong Kong as a joint venture. The economies of scale that entail from mass adoption of these cards has enabled Octopus to gain recognition as a 'bank' with a limited licence, hence offering some competition against incumbent banks. The Octopus card can be used to pay merchants, and competes as a payment initiation service with debit and credit cards. ${ }^{144}$ However, the loading and use of stored value in the card is plugged into the bank-based clearing and settlement architecture (and credit card architecture as automatic reloading by a user's bank account or credit card can be enabled).

It may be argued that peer-to-peer payment models are necessary to provide truly disruptive competition for existing payment systems. A peer-to-peer model could constitute a closed payment system on its own, achieving payment initiation, verification, clearing and settlement. At a small scale, the Octpus Oe pay system seems to achieve that as users can make peer-to-peer payments using a mobile phone number. This is however supported by Standard Chartered Bank and is open only to the bank's customers. ${ }^{145}$ In this case Standard Chartered internalises the issues of clearing and settlement by checking and updating its internal ledger, and acts as a 'mini' payment system. This is similar to the payment system of the Euro-giro ${ }^{146}$ which is a post-office based network for transfers of retail payment. Clearing and settlement are initially based on mutual accounts held by each Eurogiro member. This is now streamlined so that the Deutsche PostBank has become the settlement venue for Euro-giro transfers. In sum, peer-to-peer payment systems can constitute alternative 'mini' payment systems, but they are currently bank-based. The advent of the distributed ledger technology may present opportunities for further scaling of peer-to-peer payment systems, but their possibilities and limitations are discussed in Section B.

Have Paypal and Alipay gone further to challenge the incumbent payment architecture by providing truly large scale peer-to-peer payment systems? Paypal allows users to link bank account and credit/debit card information to their paypal account in order to initiate payment to other users. However users receiving payments can maintain balances on their paypal accounts. In this way, customers can make peer-to-peer payments using their Paypal balances like a current account, ${ }^{147}$ seemingly bypassing the prevailing bank-based clearing and settlement systems. We however think such settlement 'outside' of the bank-based clearing and settlement systems is only an accurate description of limited situations. Paypal essentially relies on either the bank-based clearing and settlement system or the in-house clearing and settlement systems of credit card consortia owned by banks to achieve finality of payment into and out of any user's account. Even if a user may be credited with funds after payment instructions are initiated by another user, the clearing and settlement processes are pending, and Paypal clearly informs users that reversals can occur if finality

\footnotetext{
${ }^{143}$ Indeed the payee runs the risk of reversal or non-settlement, see Clause 5.2, Terms and Conditions for Nets Flashpay at https://www.nets.com.sg/flashpay-tnc.

${ }^{144}$ Eric Tai, 'Incentives Keynote Address' (2005) 1 Journal of Payment Systems Law 537.

145 https://www.sc.com/hk/campaign/oepay/.

146 https://www.eurogiro.com/public-documents/Product_sheets/ESSP.pdf.

${ }^{147}$ Lawrence J Trautman, 'E-Commerce, Cyber, and Electronic Payment System Risks: Lessons from Paypal' (2016) 16 UC Davis Business Law Journal 261. The limited penetration to a full payment service is discussed in Ronald J Mann, 'Regulating Internet Payment Intermediaries' (2004) 82 Texas Law Review 681; Kevin V Tu, 'Regulating the New Cashless World' (2013) 65 Alabama Law Review 77.
} 
cannot be achieved. The user may pay another user with the balance, but both incur the clearing and settlement risk as paypal routes the payment through the established systems for clearing and settlement. Only where a user's balance has cleared and settled, and such a balance is used to pay into another user's paypal account that a truly peer-to-peer payment has been achieved. ${ }^{148}$ Hence we see Paypal acting as much more of a payment initiation service plugging into existing clearing and settlement infrastructure than a fully substitutive payment architecture. Nevertheless Paypal is regarded as a bank within the definition of credit institution ${ }^{149}$ in the EU as the maintenance of paypal balances is tantamount to deposit-taking. It is authorised in Luxembourg but does not enjoy the status of a peer clearing bank.

Alipay is an innovative way to facilitate the e-commerce of sale of goods in China by providing a delivery-versus-payment system. Users of Alipay fund their Alipay accounts via their bank accounts, debit or credit cards ${ }^{150}$ in order to pay for goods purchased online. In order to protect consumers from non-delivery of goods, Alipay keeps buyers' funds in escrow until they confirm that the goods they have bought are successfully delivered. Funds are then released to credit the seller's Alipay account. Like Paypal, Alipay acts as a payment initiation service. Ultimate clearing and settlement, i.e. from buyer to buyer's Alipay account and from seller's Alipay account to seller's bank account would have to be carried out by the bank-based clearing and settlement architecture. However, the escrow service means that Alipay accounts would be actually funded as clearing and settlement would likely have been completed for funding the buyer's Alipay account pending the delivery of goods. Hence Alipay is able to facilitate peer-to-peer payments between accounts. Further, the escrow system means that large idle balances may be sitting in Alipay at any one time, and opportunities arise for Alipay to offer financial services to its users such as investing in money market funds or even in making loans. Alipay has thus become a fully authorised financial institution in China ${ }^{151}$ and has made significant disruptive strides in becoming a new Chinese financial marketplace. However this also means that it has to be subject to the full extent of Chinese banking and investment regulation in order to meet public interest objectives in prudential management and customer protection.

Many payment innovations compete in a largely delineated space as they relate only to user initiation. Nevertheless enhanced consumer welfare can result. Payments can be made using a familiar device at home which obscures the underlying bank or credit card information, providing a sense of privacy and safety for consumers. A merchant that accepts a certain payment initiation interface may pay less fees than the interchange fees that would be levied by the card provider for direct acceptance of a credit or debit card. These outcomes are not insignificant improvements for the consumer experience, and pro-competition regulation facilitates such commercially-driven benefits. Further, the competitive impact from PISPs generates beneficial responses from the incumbent banking industry which also seeks to up its game. For example, banks have made online

\footnotetext{
148 Lawrence J Trautman, 'E-Commerce, Cyber, and Electronic Payment System Risks: Lessons from Paypal' (2016) 16 UC Davis Business Law Journal 261.

${ }^{149}$ Capital Requirements IV Directive 2013, Schedule 2 to section 19, UK Financial Services and Markets Act 2000.

${ }^{150}$ This has now extended to foreign banks and cards, see http://www.bankingtech.com/666562/alipaypartners-with-major-european-banks-and-payment-provider/.

151 'Alipay Gets Licence to Set Up E-payment System', Reuters (28 May 2011); 'Alibaba Affiliate Wins Approval to Start Private Bank', Wall Street Journal (29 Sep 2014), both approvals granted by the People's Bank of China.
} 
banking much easier and accessible to use, and UK banks in the 'Faster Payments' arrangement discussed earlier offer users the certainty of almost immediate transfers settled via RTGS in a retail framework. Banks and card providers have also joined the innovation chase, for example, in developing 'contactless' technology. ${ }^{152}$ Debit or credit cards can now be waved before a contactless terminal at merchants' points of sale for payments usually under $f 25$, improving the speeds of transactions while mitigating risk.

Although 'payment initiation service providers' are recognised as a distinct industry under the Payment Services Directive and their rights to access bank account information and verify availability of funds are safeguarded, Górka ${ }^{153}$ suggests that their inability to fully penetrate clearing and settlement systems could paradoxically augment anti-competitive effects. This is because PISPs indeed extend the reach of existing bank or card payment systems by channelling payments ultimately to the incumbent clearing and settlement systems. ${ }^{154}$ However such a phenomenon can be consistent with the need for certain trusted institutions in achieving settlement and finality in payment systems. ${ }^{155}$ We also do not think PISPs are incentivised in terms of business interests to carry out infrastructural investment into setting up alternative clearing and settlement structures to fully penetrate the payment architecture. This is far more costly than plugging into the established architecture, which as discussed in Section A, is maintained as public infrastructure. Mandatory regulation in the EU safeguards non-discriminatory access by PISPs into the payment architecture, further reinforcing the status quo. However in some cases we see how peer-to-peer payment models have grown, such as in the case of Paypal and Alipay, the latter being an example of significant disruption that can be introduced to the existing financial markets.

The delineated competition space for most PISPs is not exactly to be lamented as they are concomitantly subject to lighter regulation than the full gamut of prudential regulation applied to account service providers (ASPSPs, usually banks). Further PISPs are also subject to less onerous consumer protection regulation as account service providers bear the allocation of risk in mistaken or negligent transfers beyond $f 50$ (discussed under retail payments systems in Section A), not PISPs. ${ }^{156}$ The delineated competition space is proportionate to the lower level of public interest expectations imposed on them. We think however that emerging economies experiencing high growth in the market for PISPs would still need to address the rising importance of consumer protection as a public good, as a backlash in consumer confidence could occur if their rights in risk allocation become unpredictable with new payment interfaces. In this respect the clarification and harmonisation of rights for consumers vis a vis all types of payment service providers under the

\footnotetext{
152 Highly competitive technology, see Marc Bourreau and Marianne Verdier, 'Cooperation for Innovation in Payment Systems: The Case of Mobile Payments' (2010) at http://ssrn.com/abstract=1575036.

153 Jakub Górka, 'IBANs or IPANs? Creating a Level Playing Field between Banks and Non-bank Payment Services Providers' in Jakub Górka (ed), Transforming Payment Systems in Europe (Basingstoke: Palgrave Macmillan 2016) arguing that perhaps other non-bank payment service providers could offer IBAN accounts and have accounts at the central bank.

${ }^{154}$ Adam J Levitin, 'Payment Wars: The Merchant-Bank Struggle for Control of Payment Systems' (2007) at http://ssrn.com/abstract=981637;

${ }^{155}$ Ignacio Mas and Dan Radcliffe, 'Scaling Mobile Money' (2011) at http://ssrn.com/abstract=1681245. Alternative systems have arisen such as in Kenya using the mobile network provided by M-PESA but earlier discussion has limited the rise of such alternative phenomena to areas where bank systems are underdeveloped.

${ }^{156}$ Art 73(2), Payment Services Directive 2 (2015).
} 
Payment Services Directive 2 is an achievement, but this is not necessarily the case in other jurisdictions. ${ }^{157}$

We turn next to virtual currencies.

\section{Virtual Currencies}

The development of e-commerce has also stimulated thinking into whether exchange of value can be made in terms of e-money, as privately arisen tokens of value recognised by, for example, the online shopping community. As in barter economies, there is nothing preventing one from recognising the value in whatever goods/services sought to be exchanged. However negotiable instruments that are credible and widely accepted make commerce more efficient, and ultimately this has evolved into state-backed currency as both legal tender and token of value..$^{158}$

This is not to say that state-backed currency is an immutable institution, as there could be efficiency and public policy reasons to support privately issued currencies, such as the denationalised currency concept championed by Hayek. ${ }^{159}$ Privately issued currencies such as virtual currencies could compete with or be complimentary to state-backed currencies. Commentators identify areas where virtual currencies could be of greatest benefit: such as in oppressed countries where there may be arbitrary expropriation of monies and assets; in developing economies where currency values are less stable; ${ }^{160}$ where unbanked peoples may benefit from financial inclusion ${ }^{161}$ as bitcoin and blockchain technology can offer a low cost and reliable form of payment transfer; ${ }^{162}$ where micropayments may be made for unconventional purposes such as micro-donations or just giving someone a 'kudos'; ;63 and for circulation within closed networks such as online gaming ecosystems. ${ }^{164}$ Privately issued currencies such as bitcoin ${ }^{165}$ are supported by the blockchain as a transaction facilitating technology, but the latter may be regarded as an innovation with distinct implications other than being used for virtual currency transactions. This Section will now focus on virtual currencies as currency and money.

\footnotetext{
${ }^{157}$ Agnieszka Janczuk-Gorywoda, 'The New Transnational Payments Law and Global Consumer Trade: Online Platforms as Providers of Private Legal Orders' (2015) at http://ssrn.com/abstract=2694449.

158 Garrick Hileman, 'Alternative Currencies: A Historical Survey and Taxonomy' (2013) at http://ssrn.com/abstract=2747975.

${ }^{159}$ Friedrich Hayek, The Denationalisation of Money $(1976,1978)$ which advocates a system for privately issued bank currencies to compete, envisaging that the one/s with greatest stability in value would be preferred and ultimately result in a form of convergence. The argument is rooted in Hayek's distrust of political interference with state-backed currency. Also see Thomas L Hogan, 'Competition in Currency: The Potential for Private Money' (Cato Institute 2012) at http://ssrn.com/abstract=2224118.

${ }^{160}$ William J Luther, 'Bitcoin and the Future of Digital Payments' (2015) at http://ssrn.com/abstract=2631314.

161 Misha Tsukerman, 'The Block Is Hot: A Survey of the State of Bitcoin Regulation and Suggestions for the Future' (2015) 30 Berkeley Technology Law Journal 385.

162 Lawrence J Trautman and Alvin C Harrell, 'Bitcoin Versus Regulated Payment Systems: What Gives?' (2016) at http://ssrn.com/abstract=2730983.

163 Benedict Eikmanns and Philipp Sandner, 'Bitcoin: The Next Revolution in International

Payment Processing? An Empirical Analysis of Potential Use Cases' (2015) at http://ssrn.com/abstract=2619759.

${ }^{164}$ Andres Guadamuz and Chris Marsden, 'Blockchains and Bitcoin: Regulatory Responses to Cryptocurrencies' (2015) at http://ssrn.com/abstract=2704852.

165 How bitcoin works can be found in Larissa Lee, 'New Kids on the Blockchain: How Bitcoin's Technology Could Reinvent the Stock Market' (2016) 12 Hastings Business Law Journal 81.
} 
Consistent with this article, we critically discuss virtual currencies through an institutional perspective of money and currency. Currency is a state-backed institution that provides a standard legal tender for a sovereign jurisdiction. ${ }^{166}$ It is a Coasean efficiency institution that drives commerce and economic activity within the jurisdiction and can be regarded as a hallmark of sovereign identity. However, what is really important about state-backed currency is its moneyness which allows it to function as a medium of exchange and store of value. ${ }^{167}$ The moneyness of statebacked currency, ${ }^{168}$ fundamental to government policies and to commerce and international trade, is supported by legal institutions in private commercial law as well as banking and financial regulation. Hence, central banks are devoted to policies in calibrating currency value in order to maintain confidence in the stability of the national currency. ${ }^{169}$

However, the state or central bank are not the only ones responsible for money supply, as market demand for money would almost always outstrip what can be publicly supplied. Private creation of money via lending by credit institutions is a significant source of private money supply and it is regarded as economically efficient to allow this role as private creation of money is readier to meet economic needs. ${ }^{170}$ However, privately created money is a highly regulated activity, ${ }^{171}$ for both the interests of efficiency as well as macro-stability and public policy, and is ultimately based on statebacked currency. State-backed currency entails predictable parameters of risk management for credit institutions, and is arguably the necessary precondition for the creation of such private money. The institution of money denominated in state-backed currency serves public policy purposes in efficiency, social confidence and legitimacy. It is against this context that the role of virtual currencies is to be appraised. ${ }^{172}$

As Evans has argued, payment senders and receivers have little incentive to use a currency whose moneyness is sub-optimal, such as where currency is not widely accepted or where the value of the currency is unstable. ${ }^{173}$ Virtual currencies such as bitcoin or ethereum, whose value is not supported by the equivalent of a central bank, fluctuates according to market demand, ${ }^{174}$ which can be highly

\footnotetext{
${ }^{166}$ Chapters 1, 2.24 and 19, Charles Proctor, Mann on the Legal Aspects of Money (Oxford: OUP 2012).

167 Chapter 1, above.

${ }^{168}$ Christine Desan, Making Money: Coin, Currency, and the Coming of Capitalism (Oxford: OUP 2015); 'Money as a Legal Institution' in David Fox and Wolfgang Ernst, Money in the Western Legal Tradition (2015)

169 Daniel R. Sanches, 'On the Inherent Instability of Private Money' (2012) at http://ssrn.com/abstract=2125215.

170 Cryil Monnet, 'Private versus Public Money' (2006) 47 International Economic Review 951; Stephen D Williamson, 'Private Money and Counterfeiting' (2002) 88 Economic Quarterly 37.

${ }^{171}$ This is via bank regulation in the form of micro-prudential regulation, as well as through the use of policy tools in macro-prudential regulation where relevant. For a discussion of these areas, an introductory overview is provided in Awrey et al, Principles of Financial Regulation (Oxford: OUP 2016). Detailed discussion can be found in Simon Glesson, International Regulation of Banking (Oxford; OUP 2012), chapters 8 and 9, Iris H-Y Chiu and Joanna Wilson, Banking Regulation and Law (Oxford: OUP 2018, forthcoming); Iris H-Y Chiu, 'Macroprudential Supervision: Critically Examining the Developments in the UK, EU and Internationally' (2012) Law and Financial Markets Review 184.

172 It is opined that the success of payment innovations may depend on their fit with current institutions such as sovereign-backed currency that is supported by public confidence, see chapter 15, Andrew G Haldane, Stephen Millard and Victoria Saporta (eds), The Future of Payment Systems (London: Routledge, 2005). ${ }^{173}$ David S Evans, 'Economic Aspects of Bitcoin and Other Decentralized Public-Ledger Currency Platforms' (2014) at http://ssrn.com/abstract=2424516.

${ }^{174}$ Above, and Lawrence J Trautman and Alvin C Harrell, 'Bitcoin Versus Regulated Payment Systems: What Gives?' (2016) at http://ssrn.com/abstract=2730983.
} 
speculative. ${ }^{175}$ Further, virtual currencies are not yet widely accepted, as they are not supported by the institutional set-up of clearing and settlement, ${ }^{176}$ which, as we will shortly discuss, is not necessarily made up for by the blockchain technology. The moneyness of virtual currencies is also affected by the legal institutions that protect rights in relation to money. Low and Teo ${ }^{177}$ discuss how physical money can be protected against theft and misappropriation via criminal, tort and property laws, and money 'stored' with custodians (such as banks or other borrowers) is protected via creditors' rights. Indeed where banks are concerned, depositors are protected by state guarantee in the form of deposit protection ${ }^{178}$ and where investment is concerned, such protection is proprietary in nature even if the money cannot be traced. ${ }^{179}$

It is uncertain if users of virtual currencies enjoy like protections as the way they are stored raises certain problems, heightening users' legal risks. Virtual currency users have to store their currency (which is code) in digital wallets (which are programmes) on their computers, or on virtual currency exchanges online. Both means of storage are susceptible to cyber attacks, ${ }^{180}$ as an individual's computer can be hacked and safety of the digital wallet compromised, and so can virtual currency exchanges. Mt Gox, a then-prominent bitcoin exchange ${ }^{181}$ failed after a serious attack. As the virtual currency is code, it is uncertain whether such code can be altered. This can seriously undermine criminal, tortious or proprietary enforcement, if indeed the trail of the theft can be identified. It is also uncertain if a victim can mount a creditor's claim against an exchange like Mt Gox, as it is far from clear if the legal regime for bank deposits or investment funds should apply at all. Such a claim would certainly be futile if the exchange becomes insolvent, as was the case with Mt Gox, as established insolvency laws and their administration may also not extend to such an entity.

It may be argued that the development of a governance order can take place from the bottom-up to deal with the private rights and risks in virtual currencies. For example, in an attack against a Distributed Autonomous Organisation in 2016 which saw a third of the value of stored ethereum siphoned off by hackers, ${ }^{182}$ the founders of the ethereum virtual currency intervened to reverse the illegitimate transactions so that holders could 'recover' their ether and treat the attack as if it never

\footnotetext{
${ }^{175}$ And indeed driven by speculative 'investors' see Christian Beer and Beat Weber, 'Bitcoin - The Promise and Limits of Private Innovation in Monetary and Payment Systems' (2014) at http://ssrn.com/abstract=2556800.

${ }^{176}$ Stephen D Williamson, 'Limited Participation, Private Money, and Credit in a Spatial Model of Money' (2004) 24 Economic Theory: Symposium in Honor of Bruce D. Smith: Recent Developments on Money and Finance 857 on the necessity of central bank reserve accounts as the ultimate settlement system, and Stacey L Schreft, 'Private Money, Settlement and Discount: A Comment' (2000) at http://papers.ssrn.com/sol3/papers.cfm?abstract_id=271810.

177 Kelvin Low and Ernie Teo, 'The Legal Risks of Owning Cryptocurrencies' in Handbook of Digital Finance and Inclusion (Reed: Elseiver 2017, forthcoming) at https://papers.ssrn.com/sol3/papers.cfm?abstract_id=2856137.

${ }^{178}$ The UK's Deposit Guarantee Scheme is administered by the UK Prudential Regulation Authority and is up to f85,000 per bank customer (including multiple accounts with the same bank).

179 In the matter of Lehman Brothers International (Europe) (In Administration) and In the matter of the Insolvency Act 1986, 29 Feb 2012, [2012] UKSC 6.

${ }^{180}$ Angela Walch, 'The Bitcoin Blockchain as Financial Market Infrastructure: A Consideration of Operational Risk' (2015) 18 Legislation and Public Policy 837.

${ }^{181}$ Discussed in Kevin V Tu and Michael W Meredith, 'Rethinking Virtual Currency Regulation in the Bitcoin Age' (2015) 90 Washington Law Review 271; EBA, EBA Opinion on 'Virtual Currencies' at http://www.eba.europa.eu/documents/10180/657547/EBA- Op-2014-08+Opinion+on+Virtual+Currencies.pdf. 182 Deloitte, 'The DAO Attack' at https://www2.deloitte.com/ie/en/pages/technology/articles/DAO-AttackAnalysis.html. Also see Carla Reyes, Nizan Packin and Benjamin P Edwards, 'Distributed Governance' (2016) at https://ssrn.com/abstract=2884978.
} 
happened. However such ad hoc decisions of risk allocation are not made pursuant to any established order of governance. The decision was also not universally supported by the user community as some saw the reversal as being contrary to the original spirit of the distributed ledger technology (to be discussed shortly). Virtual currencies are at the moment not supported by any institutions that safeguard their moneyness. As will be discussed in relation to distributed ledger technologies below, virtual currency innovators have focused singularly on preventing double spending as the key and only user protection and have not addressed other risks. In sum, the appeal of virtual currencies is not likely to be widespread or substitutive in nature, given the credibility, relative stability, social acceptance of and legal infrastructure supporting many state-backed currencies.

In this context, the likely users of such virtual currencies are likely for fringe, niche or illicit purposes. A number of commentators discuss the anti-establishment ideology in bitcoin as unshackled from central bank control and the politics of state-backed currency, that can promote financial inclusion and empowerment of groups left behind by the advances in modern capitalism and financialisation. ${ }^{183}$ However, such an ideological anchor for the acceptance and legitimacy of virtual currencies would mean that use is likely confined in certain closed communities, ${ }^{184}$ or for niche purposes such as financial inclusion of the unbanked. ${ }^{185}$ In the alternative, adopters of virtual currencies wish to evade the regulated institutions for transfers of value because there may be illicit transactions involved, ${ }^{186}$ such as the use of bitcoin for the purchase of illegal drugs on Silk Road, or where money laundering may be implicated. ${ }^{187}$ These implications undermine social acceptance of virtual currencies and their legitimacy, as they are seen as anti-social and devices for legal arbitrage.

Further there are a few more impediments to wide social acceptance and legitimacy for virtual currencies. Virtual currencies like bitcoin and ether are lines of code which are open source. On the one hand, anyone can propose to modify the code and majority decision-making by the coding community ensures that only the version most users want prevails. On the other hand, if there is divided opinion on proposed modifications to code, then 'forking' can occur which undermines the network effects of a virtual currency. Further, ordinary users are unlikely to have a voice in the technology of virtual currencies and their developments. The technological development of virtual currencies, although open-source, is led by the coding community. This is referred to as the

\footnotetext{
${ }^{183}$ As a 'collaborative commons' economy, see Paolo Tasca, 'Digital Currencies: Principal Trends, Opportunities and Risks' (2015) at http://ssrn.com/abstract=2657598; or as new economic catallaxies see Trent J. MacDonald, Darcy Allen, and Jason Potts, 'Blockchains and the Boundaries of Self-Organized Economies: Predictions for the Future of Banking' in Paulo Tasca, Tomaso Aste, Loriana Pelizzon, \& Nicolas Perony (eds), Banking beyond Banks and Money (2016) at http://ssrn.com/abstract=2749514. Also see Aaron Wright \& Primavera De Filippi, 'Decentralized Blockchain Technology and the Rise of Lex Cryptographia' (2015) at http://ssrn.com/abstract=2580664.

${ }^{184}$ Andres Guadamuz and Chris Marsden, 'Blockchains and Bitcoin: Regulatory Responses to Cryptocurrencies' (2015) at http://ssrn.com/abstract=2704852.

${ }^{185}$ William J Luther, 'Bitcoin and the Future of Digital Payments' (2015) at http://ssrn.com/abstract=2631314. ${ }^{186}$ Lawrence Trautman, 'Virtual Currencies Bitcoin \& What Now: After Liberty Reserve, Silk Road, and Mt. Gox?' (2014) 20 Richmond Journal of Law and Technology 13; Rainer Böhme, Nicolas Christin, Benjamin Edelman, and Tyler Moore, 'Bitcoin: Economics, Technology, and Governance' (2015) 29 Journal of Economic Perspectives 213.

${ }^{187}$ Misha Tsukerman, 'The Block Is Hot: A Survey of the State of Bitcoin Regulation and Suggestions for the Future' (2015) 30 Berkeley Technology Law Journal 385; Danton Bryans, 'Bitcoin and Money Laundering: Mining for an Effective Solution' (2014) 89 Indiana Law Journal 441;
} 
'invisible politics of bitcoin'. ${ }^{188}$ Finally, 'earning' virtual currencies is primarily through mining, a process that produces 'proof of work' in order to validate currency transactions for the purposes of the public distributed ledger (more to be discussed shortly). ${ }^{189}$ 'Mining' is a seemingly democratic process but is competitive in nature, ${ }^{190}$ as miners pit their computing power against each other to achieve 'validation' which then has to be voted on by at least $51 \%$ of the nodes (all computers connected to the virtual currency network) in order to be recognised. In this competitive process, some miners, particularly dedicated corporate resources, can price out others by using expensive Application Specific Integrated Circuits. ${ }^{191}$ This is not to mention that mining consumes significant amounts of energy and the energy cost context for a miner becomes very important, and is certainly not a global level playing field. Individuals who cannot afford to use ASICs to out-compete can use cheaper fGPAs (field-programmable gate array) which require specialised hardware coding expertise for programming. The lack of a level playing field in mining can undermine wide social acceptance of the virtual currency as only those who can bear the cost of mining or who have specialised coding expertise will become winners in the process.

So far we do not think that virtual currencies will become institutionalised for lack of convincing bases in terms of efficiency, social confidence and legitimacy. Indeed, some jurisdictions have banned bitcoin, or subject its use to regulation so as to mitigate regulatory arbitrage such as in tax evasion or anti-money laundering. ${ }^{192}$ However regulators, being pro-innovation, may lend legitimacy by regulating virtual currency service providers, such as has been introduced by the 'bitlicence' regime in New York. ${ }^{193}$ The implication of such regulation is that the same public policy objectives in retail payment systems should be met by virtual currency service providers, including prudential requirements, anti-money laundering, security and privacy, authorisation, risk allocation and liability in payment transactions and consumer protection mechanisms. ${ }^{194}$ In the EU context for example, the Payment Services Directive 2 should apply in a non-discriminating way to virtual currency providers if they are authorised. This will enhance the cost in using virtual currency which may not be as costcompetitive as established modes of payment after all. ${ }^{195}$ The price to pay for overcoming the social deficits in bitcoin is regulatory cost, and arguably is the 'right' price, as low cost is currently possible

188 Primavera De Philippi and Benjamin Loveluck, 'The Invisible Politics of Bitcoin: Governance Crisis of A Decentralised Infrastructure' (2016) at https://ssrn.com/abstract=2852691. Such invisible politics also does not always result in consensus and fragmentary developments have occurred.

${ }^{189}$ Explained in Campbell R Harvey, 'Cryptofinance' (2014) at http://ssrn.com/abstract=2438299.

${ }^{190}$ Discussed in Lawrence Trautman, 'Virtual Currencies Bitcoin \& What Now: After Liberty Reserve, Silk Road, and Mt. Gox?' (2014) 20 Richmond Journal of Law and Technology 13 and Rainer Böhme, Nicolas Christin, Benjamin Edelman, and Tyler Moore, 'Bitcoin: Economics, Technology, and Governance' (2015) 29 Journal of Economic Perspectives 213.

${ }^{191} \mathrm{https}$ //99bitcoins.com/bitcoin-mining-worth-it/.

${ }^{192}$ Kevin V Tu and Michael W Meredith, 'Rethinking Virtual Currency Regulation in the Bitcoin Age' (2015) 90 Washington Law Review 271; Andres Guadamuz and Chris Marsden, 'Blockchains and Bitcoin: Regulatory Responses to Cryptocurrencies' (2015) at http://ssrn.com/abstract=2704852.

193 Discussed in Misha Tsukerman, 'The Block Is Hot: A Survey of the State of Bitcoin Regulation and Suggestions for the Future' (2015) 30 Berkeley Technology Law Journal 385; Lawrence J Trautman and Alvin C Harrell, 'Bitcoin Versus Regulated Payment Systems: What Gives?' (2016) at http://ssrn.com/abstract=2730983; Sarah Jane Hughes \& Stephen T. Middlebrook, 'Advancing a Framework for Regulating Cryptocurrency Payments Intermediaries' (2015) 32 Yale Journal on Regulation 495.

${ }^{194}$ Sarah Jane Hughes \& Stephen T. Middlebrook, 'Advancing a Framework for Regulating Cryptocurrency Payments Intermediaries' (2015) 32 Yale Journal on Regulation 495.

${ }^{195}$ Christian Beer and Beat Weber, 'Bitcoin - The Promise and Limits of Private Innovation in Monetary and Payment Systems' (2014) at http://ssrn.com/abstract=2556800. 
only because of the arbitrage nature of virtual currencies. ${ }^{196}$ However, regulatory legitimacy will not be able to address issues such as the lack of stability in value. Further, if forking occurs in a virtual currency, it would become uncertain as to the licensed status of any particular version. Hence, it is surmised that virtual currencies, even when put on the level playing field, is unlikely to compete with state-backed currency in the same arenas. There may however be dedicated communities of technologically conversant and fringe users. ${ }^{197}$

\section{Distributed Ledger/Organisation Technologies}

The technology that arose to support bitcoin transactions, i.e. distributed ledger technology (DLT), is poised to become the most promising disruptive innovation in fintech. DLT supports the transfer of bitcoin through a peer-to-peer network by instituting a distributed consensus methodology for validating transactions and preventing double-spending. First, a transfer is broadcast to the community of nodes (computers linked up to the peer-to-peer network). Volunteer 'miners' then compete to solve the cryptographic puzzles relating to the transfer in order to validate it, and only the proof of work voted upon by at least $51 \%$ of the nodes is accepted as valid. Upon such validation, the transfer is sealed as a block added to a public chain of validated transactions, which becomes the authoritative ledger. As the chain grows in blocks, the longest chain is taken as the ultimate ledger as approved by majority of the nodes. The DLT is devised as a key means to prevent double spending of virtual currency and its proof-of-work and majority consensus requirements ensure that the ledger maintains robust integrity and is difficult to compromise. ${ }^{198}$ The DLT also seems to offer efficient processing of transactions. Miners work in a decentralised manner, and are incentivised by payment in the virtual currency to carry out proof of work. It is estimated that verification by miners on average takes about 10 minutes.

The disruptive potential lies in the DLT's decentralised yet (apparently) authoritative nature. The use of DLT could potentially minimise the need for centralised custodians, verifying agents and centralised institutions in general in financial transactions. For example, in securities transactions, perhaps DLT could facilitate straight through processing for transfers of securities without having to go through custodians and clearing and settlement facilities and reconciliation on different brokers' internal ledgers. In payment transactions perhaps DLT could allow payor and payee to transact, and cryptographic technology would provide the means of verification, clearing and final settlement, so that payment becomes faster, more efficient and indeed safer, as decentralised payment records are simultaneously adjusted and form one single authoritative record that is indelible. ${ }^{199}$ This could

\footnotetext{
${ }^{196}$ The necessity of inducting decentralised currency into the existing regulatory framework is discussed in Harry Leinonen, 'Decentralised Blockchained and Centralised Real-time Payment Ledgers: Development Trends and Basic Requirements' in Jakub Górka (ed), Transforming Payment Systems in Europe (Basingstoke: Palgrave Macmillan 2016).

${ }^{197}$ Scalability of bitcoin is down to the fundamental deficits in social trust and confidence outlined above, and see also Max Raskin and David Yermack, 'Digital Currencies, Decentralized Ledgers,

And the Future of Central Banking' in Peter Conti-Brown \& Rosa Lastra (eds.), Research Handbook on Central Banking (Cheltenham: Edward Elgar Publishing, 2017).

${ }^{198}$ See for example Trent J. MacDonald, Darcy Allen, and Jason Potts, 'Blockchains and the Boundaries of SelfOrganized Economies: Predictions for the Future of Banking' in Paulo Tasca, Tomaso Aste, Loriana Pelizzon, \& Nicolas Perony (eds), Banking beyond Banks and Money (2016) at http://ssrn.com/abstract=2749514. 199 Possibilities explored in Marc Pilkington, 'Blockchain Technology: Principles and Applications' (2016) at http://ssrn.com/abstract=2662660; Gareth W Peters and Efsthathios Panayi, 'Understanding Modern Banking Ledgers through Blockchain Technologies: Future of Transaction Processing and Smart Contracts on the
} 
indeed disrupt the settlement and finality architecture that has remained firmly entrenched in the hands of the network of peer clearing entities.

The exploration of DLT is still emerging and the above visions are not necessarily unsound. DLT could indeed bring about institutional change for payment systems if the truly decentralised governance underlying the DLT changes the basis of social confidence and trust, from centralised and professionalised clearing and settlement ${ }^{200}$ to decentralised and technology-led, automated systems. It is also possible that such institutional change may fail to gain traction but the DLT can nevertheless be integrated into existing institutions. The first possibility would need to be supported by not just efficiency persuasions but also ideological ones. The second is largely based on efficiency persuasions alone.

For the first possibility, commentators highlight the need to accept the full ideological underpinnings of the DLT which is based on decentralised consensus and disruption of existing centers of authority and power. ${ }^{201}$ DLT requires us to accept that its alternative institution is 'trustless trust', as decentralised participants do not need to trust each other, ${ }^{202}$ but trust in the automated capacities of cryptographic technology in effecting transactions, achieving indelibility and irreversibility in the ledger.

Such institutional change or migration may be resisted on a number of grounds. First, the distributed ledger technology is not flawless. A validated transaction may only be added as a block to the ledger chain if a miner's proof of work receives $51 \%$ of the nodes' votes. It was initially thought to be impossible for anyone to control $51 \%$ of the nodes as this requires vast computing power. However, colluding groups of nodes could reach the threshold, and indeed the virtual currency Krypton was undermined by such a 51\% 'attack' which was aimed at unravelling transactions in order to facilitate double spending. ${ }^{203}$ Besides not fully being able to outlaw double spending risks, the distributed ledger technology is not able to deal with other risks and frauds ${ }^{204}$ such as theft discussed in relation to virtual currencies above. Indeed in dealing with such risks, the indelibility and irreversibility qualities of the ledger become a handicap as the 'purist' maintenance of these qualities must result in private losses being borne where they fall.

Internet of Money' (2015) at http://ssrn.com/abstract=2692487; David Mills, Kathy Wang, Brendan Malone, Anjana Ravi, Jeff Marquardt, Clinton Chen, Anton Badev, Timothy Brezinski, Linda Fahy, Kimberley Liao, Vanessa Kargenian, Max Ellithorpe, Wendy Ng, and Maria Baird, 'Distributed Ledger Technology in Payments, Clearing, and Settlement' (2016) at https://ssrn.com/abstract=2881204.

200 Sinclair Davidson, Primavera De Filippi, Jason Potts, 'Disrupting Governance: The New Institutional Economics of Distributed Ledger Technology' (2016) at http://ssrn.com/abstract=2811995.

${ }^{201}$ Scott J Shackleford and Steve Myers, 'Block-By-Block: Leveraging the Power of Blockchain Technology to Build Trust and Promote Cyber Peace' (2017) at https://ssrn.com/abstract=2874090.

202 Kevin Werbach, 'Trustless Trust' (2016) at http://ssrn.com/abstract=2844409.

203 https://cryptohustle.com/krypton-recovers-from-a-new-type-of-51-network-attack.

204 Percy Vanegas and Tomas Krabec, 'Trustless Crypto-Markets: Perceptions of Value, Risk and Cost' (2017) at https://ssrn.com/abstract=2856755; Catherine Martin Christopher, 'The Bridging Model: Exploring the Roles of Trust and Enforcement in Banking, Bitcoin and Blockchain' (2017) 17 Nevada Law Journal 1; Angela Walch, 'The Bitcoin Blockchain as Financial Market Infrastructure: A Consideration of Operational Risk' (2015) 18 Legislation and Public Policy 837; Primavera De Philippi and Benjamin Loveluck, 'The Invisible Politics of Bitcoin: Governance Crisis of A Decentralised Infrastructure' (2016) at https://ssrn.com/abstract=2852691; Kevin Werbach, 'Trustless Trust' (2016) at http://ssrn.com/abstract=2844409. 
Social trust in a system of 'trustless trust' will be undermined in the absence of a governance order in terms of risk allocation, as discussed in relation to consumer protection regulation in retail payments. As it stands, Low and Teo rightly point out that the DLT developers' singular focus on avoiding the double spending problem is narrow-minded and has not addressed a full range of institutional issues that are required to maintain social trust and confidence in the system. ${ }^{205}$ Evans also highlight the need for governance norms in automated decentralised systems as the systems comprise communities that need certain standards and norms of order ${ }^{206}$ Technology does not alone sustain the system as the human input underlying the technology is not robotically predictable. For example, the assumption that there is always and only one authoritative ledger can be undermined if a group of nodes fundamentally disagree and are determined to maintain an alternative ledger, causing a fork. This has indeed taken place with respect to the virtual currency ethereum. ${ }^{207}$ Such forks bring into question the nature of any claims and rights that depend on the ledger record for their existence and proof, and can pose serious legal risks for users. Hence, there needs to be a governance system in place in order to determine the nature and extent of rights and claims based on conflicting ledgers. This is the role played by regulation in payment systems and commentators are of the view that functionally equivalent institutions of governance ${ }^{208}$ are needed to prevent abuse and anarchy in a distributed ledger system. ${ }^{209}$

Governance should not be in the hands of coding experts alone as they may not have governance expertise, ${ }^{210}$ such as in determining the allocation of risks and rights and the extent of consumer protection needed. Coding experts may also lack financial and legal expertise in understanding the nature of the financial claims and rights that need to be verified. For example, a ledger that serves the purposes of recording security interests, such as in the rehypothecation market, must be able to accommodate a type of 'double spending', as security interests can be collaterised more than once. In the rehypothecation market, banks and financial institutions sell and repurchase highly liquid

\footnotetext{
${ }^{205}$ Kelvin Low and Ernie Teo, 'The Legal Risks of Owning Cryptocurrencies' in Handbook of Digital Finance and Inclusion (Reed: Elseiver 2017, forthcoming) at https://papers.ssrn.com/sol3/papers.cfm?abstract_id=2856137. ${ }^{206}$ David S Evans, 'Economic Aspects of Bitcoin and Other Decentralized Public-Ledger Currency Platforms' (2014) at http://ssrn.com/abstract=2424516.

${ }^{207}$ After the DAO attack discussed earlier, the founders of ethereum reversed the illegitimate transactions and changed the ledger, but a group of users fundamentally disagree with tampering with the immutability of the ledger and are determined to maintain the ledger without the intervention. Hence the ethereum ledger has forked into Ethereum one, which is the one corrected by the founders to erase the attack, and Ethereum Classic which is the alternative ledger.

${ }^{208}$ Carla L. Reyes, Nizan Packin, and Benjamin P. Edwards, 'Distributed Governance' (2016) at https://ssrn.com/abstract=2884978.

${ }^{209}$ For example Reyes argues that legal institutions should be written into the code for blockchain in order to embed governance in automated technology, see Carla L Reyes, 'Moving Beyond Bitcoin to an Endogenous Theory of Decentralized Ledger Technology Regulation: An Initial Proposal' (2016) 61 Villanova Law Review 191; while other commentators discuss the need to maintain equivalent legal institutions in supporting transactions as DLT cannot result in a lawless state which would be inefficient and socially undesirable, see Sinclair Davidson, Primavera De Filippi, Jason Potts, 'Disrupting Governance: The New Institutional Economics of Distributed Ledger Technology' (2016) at http://ssrn.com/abstract=2811995 on the importance of governing human behaviour; Stephen McJohn and lan McJohn, 'The Commercial Law of Bitcoin and Blocktrain Transactions' (2016) at http://ssrn.com/abstract=2874463. ${ }^{210}$ Kevin Werbach, 'Trustless Trust' (2016) at http://ssrn.com/abstract=2844409; Primavera De Philippi and Benjamin Loveluck, 'The Invisible Politics of Bitcoin: Governance Crisis of A Decentralised Infrastructure' (2016) at https://ssrn.com/abstract=2852691.
} 
securities in an overnight market to secure short-term loans from each other. ${ }^{211}$ These securities can be re-used multiple times in the overnight market where prior consent is obtained from the provider of the security. ${ }^{212}$ Hence, the development of the DLT would ultimately be divorced from real application if carried out in an insular manner without the participation of other experts. However, if the development eco-system for the DLT becomes more diverse, this could fundamentally change the decentralised, technology-centric nature of the DLT system itself.

It is however possible that DLT may be adopted as some aspects of its efficient technological properties can be used to improve on existing systems without the acceptance of its essentially decentralised governance and ideologies. ${ }^{213}$ This means that certain aspects of straight-through processing in transactions may be achieved, but unlikely to be in a public ledger context. Closed and permissioned systems ${ }^{214}$ could allow trusted agents to engage in straight through processing. Such closed systems involve select participants and would be fundamentally different from the community of nodes supporting an open distributed ledger. In such a case, the quality of trust in the permissioned ledger would be a type of institutional trust that exists between known, recognised and peer institutions, rather than a de-personalised trust fostered by high technology alone. Indeed, such institutional trust must be maintained at an even more stringent level if the use of permissioned ledgers allows auto-execution or straight-through processing of certain transactions. Hence there may be a need for new governance structures to secure the integrity of permissioned ledgers among small groups of participants. Commentators suggest that ultimate authoritative verification of the activities in the permissioned ledger must take place. This means that existing institutions that already perform such functions in the financial sector, such as central counterparties and auditors are unlikely to be dispensed with. ${ }^{215}$

Further, the use of permissioned ledgers and certain straight-through processing techniques may require support from changes to legal or regulatory frameworks in terms of how and when transactional certainty and security is achieved, as well as responsibility and risk allocation among participants. ${ }^{216}$ These should not be worse than the current risk and responsibility allocations in

\footnotetext{
${ }^{211}$ Stijn Claessens, Zoltan Pozsar, Lev Ratnovski and Manmohan Singh, 'Shadow Banking: Economics and Policy' (IMF Staff Discussion Note 2012) at http://ssrn.com/abstract=2187661; Manmohan Singh, 'Financial Plumbing and Monetary Policy' (IMF Working Paper 2014) at https://www.imf.org/external/pubs/ft/wp/2014/wp14111.pdf; 'Collateral and Monetary Policy' (IMF Working Paper 2013) at https://www.imf.org/external/pubs/ft/wp/2013/wp13186.pdf;

212 Under the Securities Financing Transactions Regulations 2015.

${ }^{213}$ For eg see the nuanced approach taken in IOSCO Research Report on Financial Technologies (Feb 2017).

${ }^{214}$ Eg see ESMA, 'The Distributed Ledger Technology Applied to Securities Markets' (January 2017); Gareth W Peters and Efsthathios Panayi, 'Understanding Modern Banking Ledgers through Blockchain Technologies: Future of Transaction Processing and Smart Contracts on the Internet of Money' (2015) at http://ssrn.com/abstract=2692487.

${ }^{215}$ Andre Pinna and Wieber Ruttenberg, 'Distributed Ledger Technologies In Securities Post-Trading' (ECB Occasional Paper 2016); David Mills, Kathy Wang, Brendan Malone, Anjana Ravi, Jeff Marquardt, Clinton Chen, Anton Badev, Timothy Brezinski, Linda Fahy, Kimberley Liao, Vanessa Kargenian, Max Ellithorpe, Wendy Ng, and Maria Baird, 'Distributed Ledger Technology in Payments, Clearing, and Settlement' (2016) at https://ssrn.com/abstract=2881204; Joanna Diane Caytas, 'Developing Blockchain Real-Time Clearing and Settlement in the EU, U.S., and Globally' (2016) at http://ssrn.com/abstract=2807675.

${ }^{216}$ Stephen McJohn and lan McJohn, 'The Commercial Law of Bitcoin and Blocktrain Transactions' (2016) at http://ssrn.com/abstract=2874463; Catherine Martin Christopher, 'The Bridging Model: Exploring the Roles of Trust and Enforcement in Banking, Bitcoin and Blockchain' (2017) 17 Nevada Law Journal 1; UK Government Chief Scientific Adviser, Distributed Ledger Technology: Beyond Block chain (2016) at
} 
existing payment architecture. The use of such permissioned ledgers do not, at a high level, look vastly different from the existing institutions of payment architecture, which is led by a coterie of peer clearing entities. Perhaps the use of permissioned ledgers may open up the space for joining the coterie. However we do not see the eclipse of centralised forms of verification for such systems, ie the institutions of central bank support and the institution of regulatory oversight for the public interest aspects of the payment infrastructure.

Ultimately there are efficiency as well as political reasons to resist total institutional change in payment systems based on the DLT. First, it would only be efficient and least disruptive that any adoption of the DLT is engaged with the interoperability issues with existing systems, ${ }^{217}$ but this also means that vested interests in the existing payment systems would be in prime position to determine how DLT is to be proprietised, commercialised and ultimately implemented. ${ }^{218}$ This ensures that DLT would likely be an incremental technological change for efficiency improvement ${ }^{219}$ in payment processing, such as in Santander's experiment with using DLT in reducing the clearing and settlement of foreign currency transfers to 1 business day. We do not see DLT bringing about fundamental ideological shifts for institutional migration away from the established tenets of payment systems. Perhaps this is why in exploring the use of DLT in financial services more generally, the UK Financial Conduct Authority has curiously omitted discussing payment services, ${ }^{220}$ choosing to focus on DLT in the areas of record-keeping such as in relation to client monies and assets, information collation and reporting for various compliance purposes, database creation such as for the reinsurance market and smart contracts such as in relation to investment management. We remain in need of resolving the governance and operational risks posed by DLT in payment services, even in permissioned ledgers. Hence it would seem inefficient to move away from the established institutions in large value and retail payment systems that have served both commercial objectives and public good.

\section{Conclusion}

This article has taken an institutional perspective of payment systems to analyse what existing institutions underpin today's payment infrastructure in many parts of the world. We see authoritative settlement based on central bank support as being essential for both large value and retail payment systems and the importance of consumer protection regulation for retail payment systems in the EU, UK and US. These institutions foster Coasean efficiencies in the essential coordinations that need to take place for clearing and settlement, and provide a public good infrastructure that entails social confidence and trust. The 'settled' states of these institutions are

https://www.gov.uk/government/uploads/system/uploads/attachment data/file/492972/gs-16-1-distributedledger-technology.pdf which discusses the essential leadership and legal governance that is necessary to both explore the possibilities in blockchain technology as well as to govern its adoption and use.

${ }^{217}$ ESMA, 'The Distributed Ledger Technology Applied to Securities Markets' (January 2017); IOSCO Research Report on Financial Technologies (Feb 2017).

${ }^{218}$ Such as the exploration into DLT for the Australian Stock Exchange's settlement system, known as CHESS. Also see 'With blockchain, bank cartels become bank alliances', Financial Times (28 Feb 2017).

${ }^{219}$ Which can nevertheless be very useful, see Hossein Kakavand and Nicolette Kost De Sevres in collaboration with Bart Chilton, 'The Blockchain Revolution: An Analysis of Regulation and Technology Related to Distributed Ledger Technologies' (2016) at http://ssrn.com/abstract=2849251.

${ }^{220}$ FCA, Discussion Paper on Distributed Ledger Technology (April 2017) at https://www.fca.org.uk/publications/discussion-papers/dp17-3-discussion-paper-distributed-ledgertechnology. 
not necessarily in need of competitive disruption nor should market competition be regarded as a panacea for outstanding issues for improvement. We critically discuss payment innovations against the institutional perspective of payment systems and suggest that while competition at certain levels are likely to bring social benefits through commercial developments, the maintenance of public interest objectives would necessarily delineate the scope of competition. This is not necessarily undesirable in light of the public policy needs for a stable and efficient public infrastructure and the social needs of confidence and trust in a predictable and regulated payment system that meets commercial and social expectations such as in consumer protection. 